\title{
GRAMMISTIN, THE SKIN TOXIN OF SOAPFISHES, AND ITS SIGNIFICANCE IN THE CLASSIFICATION OF THE GRAMMISTIDAE
}

\section{$\operatorname{AUTHOR}(\mathrm{S}):$}

Randall, John E.; Aida, Katsumi; Hibiya, Takashi; Mitsuura, Nobuhiro; Kamiya, Hisao; Hashimoto, Yoshiro

\section{CITATION:}

Randall, John E.... [et al]. GRAMMISTIN, THE SKIN TOXIN OF SOAPFISHES, AND ITS SIGNIFICANCE IN THE CLASSIFICATION OF THE GRAMMISTIDAE. PUBLICATIONS OF THE SETO MARINE BIOLOGICAL LABORATORY 1971, 19(2-3): 157-190

\section{ISSUE DATE:}

1971-10-30

URL:

http://hdl.handle.net/2433/175661

RIGHT: 


\title{
GRAMMISTIN, THE SKIN TOXIN OF SOAPFISHES, AND ITS SIGNIFICANCE IN THE CLASSIFICATION OF THE GRAMMISTIDAE
}

\author{
John E. RANDALL ${ }^{1}$, Katsumi AIDA2, TAKashi HIBIYA ${ }^{2}$, \\ NobUhiro MITSUURA ${ }^{3}$, HISAO KAMIYA ${ }^{3}$, \\ and YoshiRo HASHIMOTO ${ }^{3}$
}

With 23 Text-figures

\section{Introduction}

The soapfishes are named for their ability to produce large amounts of mucus, particularly if they are handled or otherwise disturbed; when confined in a small volume, the surface of the water may become frothy. In the older literature these fishes have usually been classified as the subfamily Grammistinae of the Serranidae (seabasses, groupers, etc.). Gosuine (1960) suggested that they be regarded as a family, the Grammistidae, in which he included Grammistes, Rypticus, Pogonoperca, Grammistops, and Pseudogramma and its allies. He characterized the family as follows: Whole upper border of opercle attached to the body by a flap of skin. Nasal organ dorsoventrally elongate, made up of a number of nearly parallel, longitudinally oriented lamellae (instead of the usual rosette). Mouth large; supramaxillary present. Teeth mostly villiform, many of them depressible. No enlarged scales on operculum. Upper portion of preopercular border usually with one to four projecting spines. Two (or one) pyloric cacca. Dorsal spines II to VIII. Anal with no or with III spines, in the latter instance with the last spine shorter than the penultimate. Pelvics I, 5, the inner ray attached to the abdomen by a membrane.

GosLrne noted that Diploprion of the Serranidae seemed to be the closest relative of the Grammistidae as he defined the group.

SaHultz (1966) followed Gosline in regarding the grammistids as a family. He divided it into two subfamilies, the Grammistinae and the Pseudogramminae. He distinguished the latter by its having an incomplete primary lateral line, ending beneath the soft dorsal fin (the Grammistinae have a complete lateral line), some

1 Bernice P. Bishop Museum, Honolulu, Hawaii 96818.

2 Laboratory of Fish Physiology, Faculty of Agriculture, University of Tokyo.

3 Laboratory of Marine Biochemistry, Faculty of Agriculture, University of Tokyo.

Publ. Seto Mar. Biol. Lab., XIX (2/3), 157-190, 1971. （Article 12) 
species with a secondary lateral line on the caudal peduncle, scales of moderate size and not embedded (small and often embedded in the Grammistinae), and 26 to 28 vertebrae ( 24 or 25 in the Grammistinae). He added three more genera to the Grammistinae: Rainfordia, Diploprion, and Aulacocephalus. He did not examine a specimen of Rainfordia (as is discussed in the section on classification below, it is not a grammistid). He included Diploprion and Aulacocephalus because he noted that these genera have the anterior dorsal pterygiophores associated with the first four neural spines "fundamentally the same as in Grammistes." He then contradicted himself, pointing out that the arrangement of the dorsal pterygiophores in these two genera is more serranid-like than in Grammistes and Rypticus and "cast doubt on the appropriateness of continuing to recognize the Grammistidae as a family separate from the Serranidae".

Greenwoon et al. (1966) on the other hand, recognized both the Grammistidae and Pseudogrammidac as distinct families; however these authors presented no discussion for such a classification.

While diving in the Florida Keys in 1958 the senior author became aware, in an unusual way, that something exuded from the soapfish Rypticus saponaceus is very noxious. About a $9-$ inch $(228.6 \mathrm{~mm}$ ) adult was speared in 90 feet. Rather than carry the fish all the way to the boat at the surface, it was temporarily stored inside his bathing trunks. Very soon it became apparent that a secretion from this fish was a powerful urethral irritant, and it was promptly removed from the bathing suit. Later in the Virgin Islands and Puerto Rico, conversation with fishermen revealed that keeping a soapfish in a restricted volume of seawater with other fishes often resulted in the death of the other fishes.

Maretzki and del Castillo (1967) conducted a preliminary study of the toxic property of Rypticus saponaceus in Puerto Rico. By placing a soapfish in a small volume of seawater and agitating the container, they noted that the water became foamy and opalescent. Intraperitoneal injection of crude toxin solution into mice resulted in death, often preceded by "motor unrest". Freshwater guppies, which these authors stated can survive 24 hours in seawater without obvious ill effects, were used to test the toxin in varying concentrations. In a concentrated solution the guppies almost immediately lose their sense of equilibrium and die in 3 to 5 minutes. Small reef fishes exposed to the same concentration show similar effects. The substance they found responsible for the effects was non-dialysable and insoluble in solutions of low ionic strength. Seawater solutions of the crude toxin at neutral $\mathrm{pH}$ was rapidly inactivated, but this can be delayed by shifting the $\mathrm{pH}$ in either direction. The toxin was particularly stable at $\mathrm{pH} 3-4$. It could not be extracted with diethyl ether, chloroform or methyl acetate but was soluble in water-saturated $n$-butanol. When the butanolic extract was evaporated in a porcelain dish, it was possible to achieve a partial physical separation of the yellowish gummy toxic residue from the crystalline inorganic salt deposits which collected in the bottom of the dish. The toxic residue was completely dissolved by acidification with dilute $\mathrm{HCl}$. Crude toxin solutions 
warmed to $65^{\circ} \mathrm{C}$ for 2 hours retained a high level of activity. Nevertheless, MAretzki and del Castrllo suggested that a protein or polypeptide may be responsible for or associated with the toxic effects. The results after acid hydrolysis of $n$-butanol purified toxin, followed by chromatography in a mixture of $n$-butanol, acetic acid and water $(4: 1: 1)$ revealed a number of amino acids (but no cysteine and a paucity of sulfurcontaining amino acids, in general), although the concentrate gave a negative reaction with ninhydrin prior to hydrolysis. The same preparation contained only 4.4 per cent nitrogen as determined by micro-Kjeldahl assay.

RANDALL (1967), reporting on the food habits of West Indian reef fishes, noted that no soapfishes were found in the stomachs of predatory fishes and suggested that the toxic slime of Rypticus might be repelling to predators.

Liguori et al. (1963) demonstrated that the golden-striped soapfish (Grammistes sexlineatus) of the tropical Indo-Pacific region secreted copious amounts of viscid mucus by tactile stimulation which had both antibiotic and toxic activity. Both aqueous and 95\% ethanolic extracts of lyophilized mucus inhibited the growth of Escherichia coli when assayed by the paper disc method on plate cultures at $37^{\circ} \mathrm{C}$. The fish Fundulus heteroclitus was killed in one hour or less when immersed in a solution of 70 or more parts per million of the ethanol extractable material. The symptoms were primarily neurological. Striking effects were produced on sea urchin egg development. Various concentrations were capable of immobilizing sperm and causing cytolysis of unfertilized eggs.

Hashimoto and Kamiya (1969) investigated the toxic substance in the skin of another Indo-Pacific soapfish, Pogonoperca punctata. Skin extracts force-fed in capsules to cats or injected subcutaneously induced ciguatera-like effects. The cats displayed diarrhea, followed by a loss of motor activity. Vomiting and increased salivation were frequently observed. Paralysis of the limbs and coma occurred within a few days. Extracts of the muscle tissue of the fish were nontoxic at a level of $10 \%$ body weight. Intraperitoneal injections in mice resulted in paralysis of the hind limbs; labored breathing and death. The minimum lethal dose was $320 \mu \mathrm{g}$ per gram, equivalent to $70 \mathrm{mg}$ of the raw skin; death time was 24 to 48 hours. When immersed in a solution of the toxin, the medaka or Japanese ricefish (Oryzias latipes) showed motor excitation, followed by a loss of equilibrium and death. The minimum lethal dose was $0.78 \mathrm{mg}$ per $50 \mathrm{ml}$ (or $15.6 \mathrm{ppm}$ ). Hemolytic activity was demonstrated using a $2 \%$ rabbit blood cell suspension. No hemolytic activity was detected from extracts of flesh, liver, and viscera other than liver. The toxin is only partially extractable with water, physiological saline, $10 \%$ acetic acid or hot ethanol, but effectively with hot $70 \%$ ethanol. It is soluble in $n$-butanol and $n$-amyl alcohol but insoluble in diethyl ether, petroleum ether, or chloroform. In an alkaline medium ( $\mathrm{pH} \mathrm{12)}$ it is heat labile. About $80 \%$ of the hemolytic activity is lost on heating in a bath of boiling water for 15 minutes. No marked loss of activity, however, may be observed when heating on the acidic side ( $\mathrm{pH} 2)$. 
On thin-layer chromatography, the preparation partially purified by precipitation with $\mathrm{NaCl}$ and subsequent extraction with $n$-butanol consisted of four or five toxic components, each positive to the Dragendorff reagent and negative to both the biuret and ninhydrin reagents. Dialysis carried out against 50 volume of distilled water at $5^{\circ} \mathrm{C}$ for 5 hours resulted in $35 \%$ of the original activity being found in the outer solution and $60 \%$ in the tube.

A comparison was made between ostracitoxin ${ }^{1}$, the external toxin of trunkfishes (Ostraciontidae) and the toxin of Pogonoperca. Although there is some resemblance in pharmacological properties, the soapfish toxin displays differences in other respects. The toxin from Pogonoperca is extractable from the skin of a frozen fish whereas that from ostraciontid fishes may be obtained only from live fishes. Also there are distinct dissimilarities in thin-layer chromatography and in solubilities. For example, ostracitoxin is soluble in chloroform. It was noted that the toxin from Pogonoperca behaves similarly to that of Rypticus as reported by Maretzki and del Castillo.

Hasmmoto and KamiYa also obtained an ichthyotoxin from the skin of Grammistes sexlineatus and found by thin-layer chromatography that it consisted of three components corresponding to those of the toxin from Pogonoperca punctata. They suggested that the same or similar toxins might be widespread within the soapfish family. This concept has provided the stimulus for the present paper.

\section{Investigation of the Toxin}

Taste Test: We found that placing a small amount of the mucus of soapfishes on one's tongue results in an immediate unpleasant bitter taste and slight stinging sensation which is presumably due to the skin toxin of these fishes. If these fishes are confined to a small volume of water and agitated, the taste may be detected in the water. This water easily forms a long-lasting foam like a soap solution when shaken vigorously.

The direct tasting of mucus provides a rapid method of initial screening for toxin. With this taste test we have determined that all of the grammistids which occur in the tropical Pacific, plus the four species of Rypticus that were examined alive or freshly dead, were positive for the toxin.

The specimens of Grammistes sexlineatus and Pogonoperca punctata for testing of toxicity were obtained from the Ryukyu Islands, and those of Aulacocephalus temmincki and Diploprion bifasciatum from the Seto Marine Biological Laboratory in southern Honshu. Grammistops ocellatus was taste tested in Tahiti, Rypticus saponaceus, $R$. subbifrenatus, and $R$. randalli were initially examined in Puerto Rico and later Japan.

1 Ostracitoxin was named by Thomson (1964). Boylan and Scheuer (1967) named it pahutoxin. The earlier name of THOMson is preferred, however, for it refers to Ostracion the well-known type genus of the trunkfish family, whereas the term proposed by Boylan and SaHeuter draws on a Hawaiian fish name which is rarely used. 
Rypticus bicolor was collected and tested in the Gulf of California. Subsequent tests were made on a live individual shipped to Japan.

The following 16 serranid fishes were also taste-tested from freshly dead or live material obtained from the Central Wholesale Market of Tokyo, Ueno Zoo Aquarium, Enoshima Aquarium, Keikyu-Aburatsubo Marine Park Aquarium, and the Nagasaki Aquarium: Doderleinia berycoides, Lateolabrax japonicus, Coreoperca kawamebari, Cephalopholis argus, C. urodelus, Epinephelus akaara, E. awoara, E. caeruleopunctatus, $E$. fario, E. fasciatus, E. hoedtii, E. merra, E. moara, E. septemfasciatus, Stereolepis ischinagi, and Variola louti. Drs. Tokiharu ABE and Fujio YASUdA assisted in the identification of these fishes. All were obviously negative for the characteristic bitter taste of grammistids except Epinephelus merra and E. ischinagi for which the first tester reported slight reactions. Subsequent taste tests for these species, plus tests for hemolytic activity, were all negative.

Similarly, taste tests were performed on the following pseudogrammid fishes, after being collected at Central Pacific localities: Pseudogramma polyacantha, Aporops bilinearis, and Suttonia lineata. All were negative for the toxin.

In addition to the bitter taste, the senior author noted that the mucus of Grammistes and Pogonoperca has a distinctive pungent and unpleasant odor, and after handling these fishes, one's hands smell of it. The purified skin toxin of these fishes has no detectable odor, however.

With something so subjective as tasting, it is difficult to make a precise assessment of the relative strength of the skin toxin of a fish. Also the amount of toxin produced by an individual fish varies with the degree of stress to which it is exposed, and probably other factors as well. Nevertheless it seemed evident that the strongest taste could be obtained from Grammistes sexlineatus. The mucus of Pogonoperca punctata also produced a strong taste. That of Grammistops ocellatus and Rypticus, by comparison, was relatively weak. The four species of Rypticus tested could be rated by the strength of the bitter taste as follows: bicolor $>$ saponaceus $>$ subbifrenatus $>$ randalli. Aulacocephalus temmincki and Diploprion bifasciatum were about equal in their taste reaction and intermediate to Grammistes and Pogonoperca on one hand and Grammistops and Rypticus on the other.

Ichthyotoxic Activity: Tests were conducted on the effect of the secretions of Grammistes sexlineatus, Aulacocephalus temmincki, and Diploprion bifasciatum on nongrammistid fishes similar to that carried out by Наsнimoto and Kamiya (1969) on Pogonoperca punctata.

When a live Grammistes sexlineatus $93 \mathrm{~mm}$ in standard length (SL) was kept in $150 \mathrm{ml}$ of distilled water for 1.5 minutes, the water became turbid and foamy. Five individuals of Oryzias latipes placed in this water died in 11 minutes on the average.

One Diploprion bifasciatum $158 \mathrm{~mm}$ in standard length was agitated in $800 \mathrm{ml}$ of seawater for 5 minutes. Five adults of $O$. latipes were then placed in this water. They showed immediate motor excitation and died within 15 minutes. Although a fresh- 
water species, $O$. latipes can ordinarily survive in seawater for at least a day.

An individual of Aulacocephalus temmincki about $200 \mathrm{~mm}$ in standard length was kept under agitation in $400 \mathrm{ml}$ of seawater for 3 minutes. One $O$. latipes was killed in 81 minutes when placed in this water, and a girellid fish (Girella punctata) succumbed in 63 minutes in the same water.

Tests were also made of the effect of partially purified toxin from the mucus and skin of the following soapfishes on live O. latipes: P. punctata, G. sexlineatus, D. bifasciatum, A. temmincki, G. ocellatus, and $R$. saponaceus. The tests were run with the same $n$-butanolic extracts as used for the investigation of hemolytic activity (see below). One saponin unit of toxin (determined from the hemolytic activity equivalent to 1 mg of standard saponin) from each of the six species was dissolved in separate containers containing $50 \mathrm{ml}$ of distilled water at $20^{\circ} \mathrm{C}$. Five live medaka were placed in each container and the death time of the fish recorded. The results are shown in Table 1. They indicate that the relationship between hemolytic and ichthyotoxic activity is similar regardless of the species of soapfish.

Table 1. The death time of medaka (Oryzias latipes) in solutions of skin toxin from grammistid fishes.

\begin{tabular}{c|c|c|c|c|c|c}
\hline \hline Species & $\begin{array}{c}\text { Pogonoperca } \\
\text { punctata }\end{array}$ & $\begin{array}{c}\text { Grammistes } \\
\text { sexlineatus }\end{array}$ & $\begin{array}{c}\text { Diploprion } \\
\text { bifasciatum }\end{array}$ & $\begin{array}{c}\text { Aulacocephalus } \\
\text { temmincki }\end{array}$ & $\begin{array}{c}\text { Grammistops } \\
\text { ocellatus }\end{array}$ & $\begin{array}{c}\text { Rypticus } \\
\text { saponaceus }\end{array}$ \\
\hline $\begin{array}{c}\text { Death time } \\
\text { (min.) }\end{array}$ & $\begin{array}{l}68,80,84 \\
84,100\end{array}$ & $\begin{array}{l}61,64,68 \\
78,84\end{array}$ & $\begin{array}{l}84,88,90 \\
91,95\end{array}$ & $\begin{array}{l}68,71,71 \\
72,111\end{array}$ & $\begin{array}{l}47,95,102 \\
116,120\end{array}$ & $\begin{array}{l}72,95,103 \\
125,130\end{array}$ \\
\hline Average & 83 & 69 & 89 & 79 & 96 & 105 \\
\hline
\end{tabular}

Effect of a Soapfish on a Predator: On December 4, 1968 it was noted that a Grammistes sexlineatus $21 \mathrm{~mm}$ in standard length was eaten during the night by another fish of the same species $38 \mathrm{~mm}$ in standard length in an aquarium at the Eniwetok Marine Biological Laboratory, Eniwetok Atoll, Marshall Islands. Since grammistids do not die in water in which they have been provoked into liberating skin toxin which kills other fishes in the same container, it is presumed that they are tolerant of their own toxin. They would not, therefore, be expected to be deterred by the toxin in feeding. As mentioned previously, it has been hypothesized that the skin toxin of grammistids is repelling to predators. To test this, the $38-\mathrm{mm} \mathrm{G}$. sexlineatus was placed in a large aquarium at Eniwetok which contained a lionfish (Pterous volitans) about $150 \mathrm{~mm}$ in standard length which was routinely fed small live fishes as food. Before the little grammistid had reached the bottom of the aquarium, the lionfish was already in slow pursuit. It soon seized the soapfish in its jaws, but immediately expelled it. It made two expelling movements of its mouth after the fish was released, suggesting that a lingering bad taste was being experienced. No further attempt was made by the Pterois to eat the Grammistes.

Hemolytic Activity: The skin toxin of grammistids causes hemolysis of rabbit blood 
cells. Hemolytic activity was tested for six species of these fishes. For Pogonoperca punctata, Grammistes sexlineatus, and Grammistops ocellatus the test solutions were prepared by first grinding up the skin without removing the mucus and washing with distilled water. The residue was then extracted three times with hot $70 \%$, ethanol for 30 minutes. The three extracts were combined and concentrated in vacuo, acidified with acetic acid, and defatted with diethyl ether. The residue was then dissolved in distilled water. Some of this solution was used for testing, and some was extracted three times with $n$-butanol; the three $n$-butanol layers were combined, the residue dissolved in distilled water, and this also used for testing.

The test solutions for Diploprion bifasciatum, Aulacocephalus temmincki, and Rypticus saponaceus were made from the mucus and then the skin with the external mucus removed. The mucus was carefully scraped off the skin, suspended in $50 \mathrm{ml}$ of distilled water and shaken three times with an equal volume of $n$-butanol. The $n$-butanol layers were combined and evaporated to dryness under reduced pressure. The residue was dissolved in distilled water and acidified with acetic acid. The skin freed from slime was treated in the same manner as the first three species mentioned.

Hemolytic activity was determined with $2 \%$ rabbit blood cell suspension by the method given by Yasumoto, Watanabe, and Hashimoto (1964) for asterosaponin. The results (Table 2) are expressed in terms of saponin units (S.U.). One saponin

Table 2. The hemolytic activity of skin and mucus toxins of grammistid fishes

\begin{tabular}{|c|c|c|c|c|c|c|}
\hline \multirow{3}{*}{ Species } & \multirow{3}{*}{ No. } & \multicolumn{3}{|c|}{ Skin } & \multirow{2}{*}{\multicolumn{2}{|c|}{$\frac{\text { Mucus }}{\text { n-BuOH Ext. }}$}} \\
\hline & & \multicolumn{2}{|c|}{ Hot $70 \%$ EtOH Ext. } & \multirow{2}{*}{$\frac{\text { n-BuOH Ext. }}{\text { S.U./mg }}$} & & \\
\hline & & S.U./g skin & S.U./mg & & S.U./g mucus & S.U./mg \\
\hline $\begin{array}{r}\text { Pogonoperca } \\
\text { punctata }\end{array}$ & $\begin{array}{r}3 \\
4 \\
5 \\
6 \\
7 \\
8 \\
9 \\
10\end{array}$ & $\begin{array}{r}17.4 \\
51.8 \\
3.5 \\
8.0 \\
19.2 \\
15.6 \\
19.5 \\
20.5\end{array}$ & $\begin{array}{l}0.75 \\
0.99 \\
0.10 \\
0.26 \\
0.41 \\
0.27 \\
0.22 \\
0.23\end{array}$ & $\begin{array}{l}0.78 \\
1.70 \\
0.21 \\
0.53 \\
0.58 \\
0.50 \\
0.91 \\
0.94\end{array}$ & & \\
\hline $\begin{array}{l}\text { Grammistes } \\
\quad \text { sexlineatus }\end{array}$ & $\begin{array}{l}6 \\
7\end{array}$ & $\begin{array}{l}31 \\
25\end{array}$ & $\begin{array}{l}0.36 \\
0.31\end{array}$ & $\begin{array}{l}2.3 \\
0.86\end{array}$ & & \\
\hline $\begin{array}{l}\text { Diploprion } \\
\quad \text { bifasciatum }\end{array}$ & $\begin{array}{l}1 \\
2 \\
3\end{array}$ & $\begin{array}{l}0.22 \\
0.18 \\
0\end{array}$ & $\begin{array}{l}0.004 \\
0.003 \\
0.003\end{array}$ & 0.02 & $\begin{array}{l}1.2 \\
0.8 \\
1.8\end{array}$ & $\begin{array}{l}0.15 \\
0.05 \\
0.09\end{array}$ \\
\hline $\begin{array}{r}\text { Aulacocephalus } \\
\text { temmincki }\end{array}$ & $\begin{array}{l}1 \\
2 \\
3\end{array}$ & $\begin{array}{l}0.14 \\
0.30 \\
0.21\end{array}$ & $\begin{array}{l}0.002 \\
0.004 \\
0.003\end{array}$ & 0.16 & $\begin{array}{l}1.0 \\
1.9 \\
3.2\end{array}$ & $\begin{array}{l}0.03 \\
0.08 \\
0.08\end{array}$ \\
\hline $\begin{array}{r}\text { Grammistops } \\
\text { ocellatus }\end{array}$ & 1 & 1.67 & 0.15 & 0.60 & - & 一 \\
\hline $\begin{array}{l}\text { Rypticus } \\
\text { saponaceus }\end{array}$ & 1 & 0.21 & 0.04 & 0.15 & 1.6 & 0.04 \\
\hline
\end{tabular}


unit is the hemolytic activity equivalent to $1 \mathrm{mg}$ of standard saponin (Merck, B6, Darmstadt).

For the three species in which a separate test was made on the mucus, it is evident that much more toxin is found in the mucus than the skin alone. Considerable individual variation is evident within a species, undoubtedly reflecting in part the treatment of the individual fishes prior to their death. Nevertheless it seems evident that more toxin may be found per unit of skin in Grammistes sexlineatus and Pogonoperca punctata than the other species.

The same procedure for testing hemolytic activity of $G$. sexlineatus and $P$. punctata was carried out for a specimen of the pseudogrammid fish Suttonia lineata from Hawaii $75 \mathrm{~mm}$ in standard length. No hemolysis of the rabbit blood cells was detectable for this species.

Thin-layer Chromatography: The preparations for determination of hemolytic activity obtained by extraction with $n$-butanol were examined by thin-layer chromatography. Each resulted in several components which were positive to the Dragendorff reagent. The toxic components were located on the cellulose plate by spraying with $2 \%$ rabbit blood cell suspension. The spots with hemolytic activity were almost the same as those positive to the Dragendorff reagent. The $\mathrm{Rf}$ values obtained are summarized in Table 3; those of the main spots are underlined. The patterns of the chromato-

Table 3. Thin-layer chromatogram of the skin toxin of grammistid fishes.

\begin{tabular}{|c|c|c|}
\hline Species & I & II \\
\hline Pogonoperca punctata (skin) & $0.50,0.45,0.43,0.37$ & $\underline{0.52,0.39,0.31,0.26,0.08}$ \\
\hline Grammistes sexlineatus (skin) & $0.75,0.58,0.51,0.44,0.36$ & $0.57,0.51,0.46,0.41,0.32$ \\
\hline Diploprion bifasciatum (mucus) & $0.90,0.75,0.58 \underset{\text { (tailing) }}{0.51, \sim 0.35}$ & $0.71,0.51,0.63,0.39,0.27$ \\
\hline Aulacocephalus temmincki (mucus) & $0.90,0.75,0.58, \underset{0.50 \sim 0.30}{(\text { tailing })}$ & $\underline{0.79}, 0.53,0.42,0.34$ \\
\hline Grammistops ocellatus (skin) & $0.60,0.50,0.40$ (weak) & $0.70 \sim 0.40$ (tailing, weak) \\
\hline Rypticus saponaceus (mucus) & $0.91, \underline{0.52}, 0.35$ & $0.75,0.63,0.53,0.34$ \\
\hline
\end{tabular}

System: I. Cellulose $\ldots . n-\mathrm{BuOH}: \mathrm{EtOH}: \mathrm{H}_{2} \mathrm{O}(4: 1: 2)$

II. Kieselgel G...n-BuOH $: n-\mathrm{PrOH}: 0.1 \mathrm{~N} \mathrm{HCI}(1: 1: 1)$

grams for the different species were similar to each other. The spots for Grammistops ocellatus were not as clear, however. This was probably due to initial preservation of the specimen in 10\% formalin, followed by soaking in water, and storage in $40 \%$ isopropanol. 
For comparison, the Rf values for ostracitoxin or pahutoxin are 0.81 (System I) and 0.50 (System II).

Properties of Purified Skin Toxin: The preparations of skin toxin of three of the grammistid fishes, Grammistes sexlineatus, Pogonoperca punctata, and Rypticus saponaceus, were further purified by silicic acid column chromatography. The hemolytic activity and certain chemical and physical properties are summarized in Table 4. We also attempted to purify the skin toxin from Diploprion bifasciatum but could only obtain a preparation of very low purity.

Although there were some differences in the relative amounts of the various amino acids, the four dominant amino acids were the same for all three species. We do not know to what extent the differences in composition of amino acids, ultraviolet and infrared spectra may be attributed to the different purity of the preparations from the different species or how much may be due to possible differences in the chemical structure of the toxin of the different species (see Table 4). More detailed biochemical study of the skin toxin in grammistids is now in progress.

Table 4. Properties of the skin toxin of grammistid fishes.

(Each preparation was purified by silicic acid column chromatography.)

\begin{tabular}{l|c|c|c}
\hline \multicolumn{1}{c|}{ Species } & Grammistes sexlineatus & Pogonoperca punctata & Rypticus saponaseus \\
\hline $\begin{array}{l}\text { Hemolytic activity } \\
\text { (S.U./mg dried residue } \\
\text { of extract) }\end{array}$ & 4.55 & 3.08 & 0.11 \\
\hline Dragendorff reagent & + & + & + \\
\hline $\begin{array}{l}\text { Dominant Amino Acid } \\
\text { Phenylalanine, Glycine }\end{array}$ & $\begin{array}{l}\text { Leucine, Isoleucine, } \\
\text { Phenylalanine, Glycine }\end{array}$ & $\begin{array}{l}\text { Leucine, Isoleucine, } \\
\text { Phenylalanine, Glycine }\end{array}$ \\
\hline $\begin{array}{l}\text { Total nitrogen (\%) } \\
\text { (\% of total nitrogen) }\end{array}$ & 12.7 & 10.1 & 8.8 \\
\hline $\begin{array}{l}\text { Amino acid nitrogen* } \\
\left.\text { Infrared - IR (cm }{ }^{-1}\right)\end{array}$ & 1660,1530 (peptide) & 1655,1540 (peptide) & 1660,1540 (peptide) \\
\hline Ultraviolet - UV (m $\mu)$ & 258 & 91 & 245 \\
\hline
\end{tabular}

* Nitrogen of ammonia detected in amino acid analysis is included.

Histological Investigation: Histological preparations were made of the skin of nine species of soapfishes. Those of Grammistes sexlineatus, Rypticus bicolor, Diploprion bifasciatum, and Aulacocephalus temmincki were the most satisfactory, for these fishes were available alive. The other preparations were made from frozen or preserved specimens; the epidermis was sufficiently altered on these to preclude adequate study of surface mucous cells. 
Two types of mucous cells in the epidermis and well-developed mucous glands in the dermis under the scales were found in the skin of both Grammistes sexlineatus (Figs. 1-3) and Rypticus bicolor (Figs. 4-6). The first type of mucous cell (here designated Type I) is the usual type found in the epidermis of fishes in general. On both $G$. sexlineatus and $R$. bicolor these are small and arranged along the upper layer of the epidermis. They are positive to PAS reaction and negative to Sudan Black B staining. The second kind of mucous cell (Type II) is negative to the PAS reaction and positive to Sudan Black B staining. To our knowledge, this cell type is not found in nongrammistid fishes. In Grammistes sexlineatus, the smaller cells of this type are found at the upper layer of the epidermis; the larger cells, or possibly mucous depots which contain many small granules stainable with Sudan Black B, are found in the lower layer. In $R$. bicolor mucous cells of Type II are found only in the lower layer. In both species, the dermal mucous glands have a duct leading to the epidermal surface and are composed of small compartments. Material in these glands, being PASnegative, is strongly stained with Sudan Black B, and presumably is discharged through the duct to the exterior of the fish.

The skin toxin of Grammistes and other soapfishes also stains positive (black) with Sudan Black B.

Pogonoperca punctata, Grammistops ocellatus, Rypticus randalli, $R$. saponaceus, and $R$. subbifrenatus have the same type of dermal mucous glands as Grammistes sexlineatus and Rypticus bicolor. As stated, the epidermis of these five were not examined due to alteration from preservation and freezing.

Diploprion bifasciatum and Aulacocephalus temmincki, on the other hand, lack the dermal mucous glands. They have both types of mucous cells in the epidermis, however, as may be seen in the histological sections of Figs. 7 to 9 for D. bifasciatum and Figs. 10 to 12 for $A$. temmincki.

Discussion: The skin toxin of the different grammistid fishes seems to be the same or very similar in all of the species investigated. All gave the same distinctive bitter taste. Each preparation could be extracted and purified by the same procedures, including the extraction with hot $70 \%$ ethanol, $n$-butanol extractions, and silicic acid column chromatography. All displayed similar thin-layer chromatograms, and they showed essentially the same ratio between ichthyotoxic and hemolytic activity. Each preparation consisted of a peculiar peptide with a moiety of tertiary or quarternary amine. Special mucous cells stainable with Sudan Black B were found in all the genera. The purified skin toxin is also stained by Sudan Black B.

We propose at this time to name the toxin grammistin. If differences are ultimately demonstrated in its chemical structure among the species, we believe they will be minor and may be given subsidiary designations such as $A, B, C$, etc.

Grammistin is distinct from ostracitoxin, the skin toxin of trunkfishes (Ostraciontidae). As mentioned in the Introduction, there are noteworthy differences in the thin-layer chromatograms and in solubilities. There are also histological dif- 


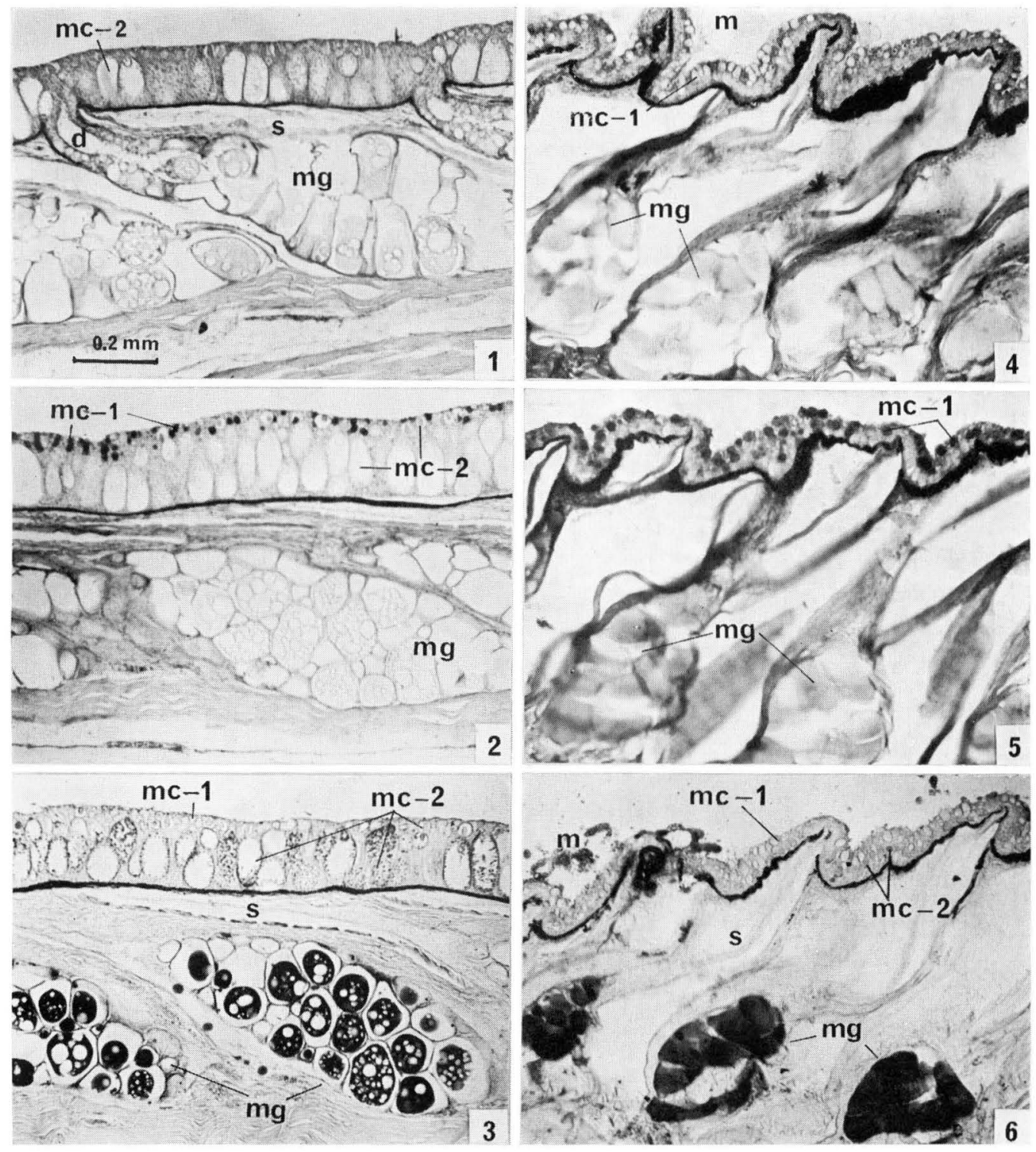

Figure 1. Grammistes sexlineatus, Hematoxylin-eosin preparation.

Figure 2. Grammistes sexlineatus, PAS-hematoxylin preparation.

Figure 3. Grammistes sexlineatus, Sudan Black B preparation.

Figure 4. Rypticus bicolor, Hematoxylin-eosin preparation.

Figure 5. Rypticus bicolor, PAS-hematoxylin preparation.

Figure 6. Rypticus bicolor, Sudan Black B preparation.

(mc-1 = mucous cell, Type I; mc-2 = mucous cell, Type II $; \mathrm{mg}=$ mucous gland; $\mathrm{s}=$ scale; $\mathrm{m}=$ mucus; $\mathrm{d}=$ duct. Same magnification for all figures) 

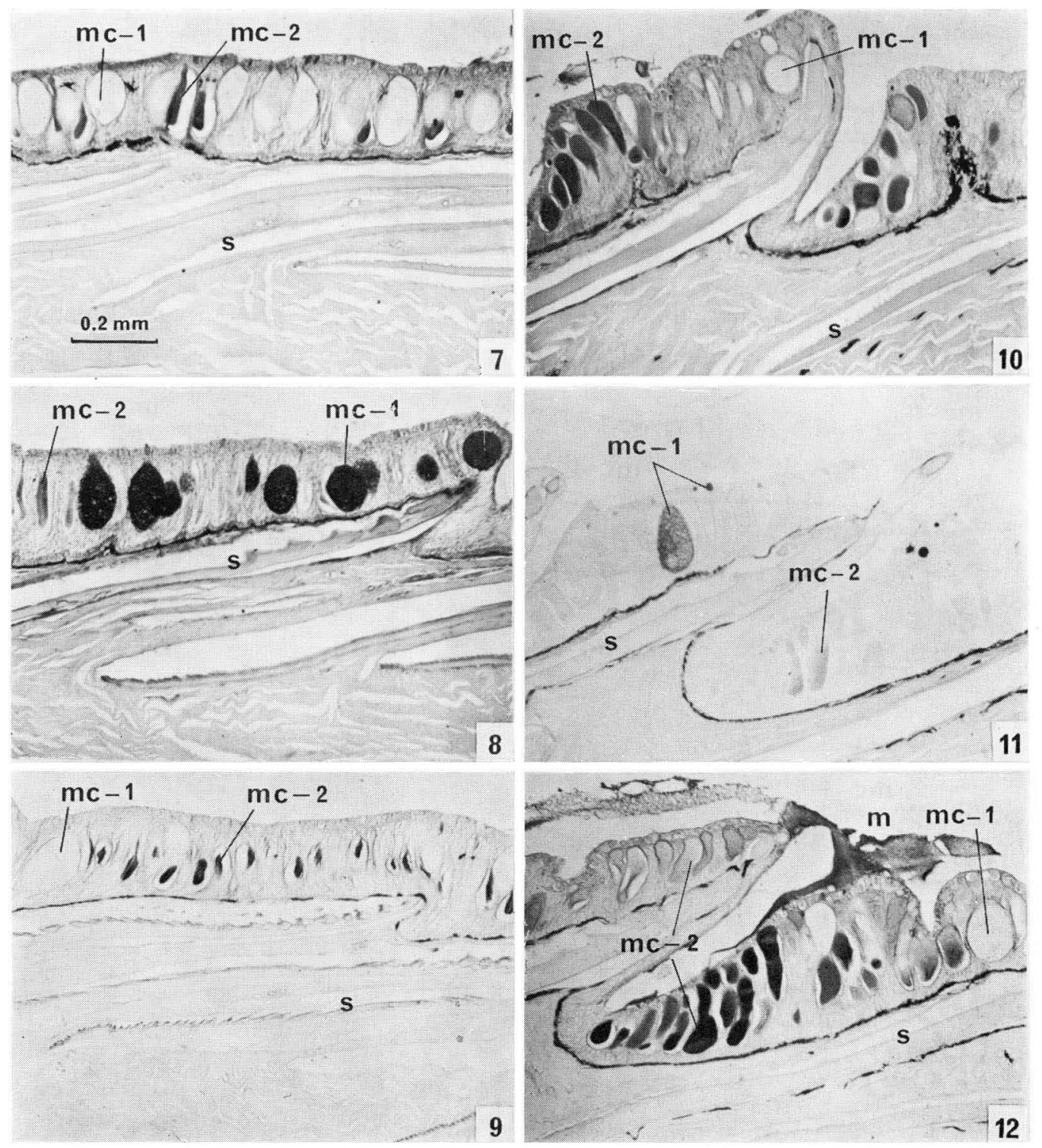

Figure 7. Diploprion bifasciatum, Hematoxylin-eosin preparation.

Figure 8. Diploprion bifasciatum, PAS-hematoxylin preparation.

Figure 9. Diploprion bifasciatum, Sudan Black B preparation.

Figure 10. Aulacocephalus temmincki, Hematoxylin-eosin preparation.

Figure 11. Aulacocephalus temmnicki, PAS preparation.

Figure 12. Aulacocephalus temmincki, Sudan Black B preparation.

(See foot-note of the preceeding page) 
ferences in the glands believed responsible for secreting the toxins. Those in Ostracion are in the form of club-shaped single cells or simple multicellular glands derived from them. These cells lie in mid-epidermis (Thomson, 1968). With the exception of Diploprion and Aulacocephalus, the grammistids have simple tubular or alveolar glands in the dermis, in addition to unicellular glands in the epidermis.

As will be seen from the section on Classification below, Diploprion and Aulacocephalus are morphologically intermediate to the Serranidae and the remaining fishes of the Grammistidae in a number of respects. The lack of multicellular toxin-secreting glands in the dermis of these fishes is an additional feature suggesting that they are primitive members of the family.

The unique color patterns of Grammistes and Aulacocephalus, and to a lesser extent Diploprion and Pogonoperca are more distinctive than those of most serranid fishes. One might assume that these patterns serve as warning coloration to potential predators. Rypticus and Grammistops, on the other hand, are very drab. The species of Rypticus appear to be mainly nocturnal (see below), and the individuals of Grammistops we have collected have all been taken with rotenone from deep recesses in caves (the fish were not seen prior to the liberation of the poison). Possibly the species of these two genera are more retiring by day than other soapfishes and thus would have less need for colors that would serve to advertise their unpleasant skin exudation.

\section{Classification}

As discussed in the previous section, the presence of grammistin in the genera Grammistes, Pogonoperca, Grammistops, Rypticus, Aulacocephalus, and Diploprion is an additional unifying principle for the group, thus making a stronger case for family status. Conversely, the absence of the toxin from Pseudogramma and related genera, along with the difference in structure of the lateral line, more vertebrae and fewer scales, provides a more convincing separation of this group from the Grammistidae. Also the small size of the pseudogrammids might be mentioned. The maximum SL for the family is about $90 \mathrm{~mm}$.

The family Grammistidae may be defined collectively by the following characters: upper border of opercle attached to body by a flap of skin; mouth large, the lower jaw projecting, the maxillary extending to or posterior to a vertical through center of eye; supramaxillary present; teeth in villiform bands in jaws and on vomer and palatines; 3 opercular spines (except one species of Rypticus with 2); preopercular margin strongly serrate or with 1 to 4 spines; head and body moderately to strongly compressed, the width of body behind gill opening contained about 2 to 3.5 times in maximum depth; interorbital slightly to strongly convex; ventral profile of head usually jutting below that of thorax; a single complete lateral line; scales small, often embedded, about 75 to 140 rows between origin of lateral line and caudal base; no enlarged scales on operculum; one or two dorsal fins (when two, not separated at 
base); borders of caudal, pectoral, and soft portions of dorsal and anal fins bluntly rounded; branched caudal rays 15 (except Rypticus with 16 or 17); dorsal spines II to IX; dorsal soft rays 12 to 27; anal spines 2 or 3 (except Rypticus which has none); anal spines, when present, very short, the longest half or less than half the length of longest anal soft ray; anal soft rays 8 to 17 ; pectoral rays 13 to 18 ; pelvic rays $I, 5$, the last ray broadly joined to abdomen by a membrane; origin of pelvic fins below or anterior to base of pectoral fins; gill membranes free from isthmus, those of the two sides barely connected anteriorly; branchiostegal rays 7 ; vertebrae 24 or 25 ; one interneural spine (pterygiophore) between second and third neural spines and two interneurals between third and fourth neural spines; a free interneural (predorsal) near tip of first interneural spine and a second near tip of second interneural spine; two nasal openings on each side, the anterior in a short tube with posterior edge longer; nasal organ either a rosette or vertically elongate; skin with a thick coat of viscid mucus containing the toxin grammistin, believed secreted by special mucous cells which stain dark with Sudan Black B.

In his excellent publications on serranid fishes, Katayama (1959, 1960a, 1960b) placed Diploprion and Aulacocephalus in a separate subfamily, Diploprioninae, from the Grammistinae. The first character used in his key to subfamilies to distinguish the two groups is the greater convexity of the interorbital region of the Diplorioninae. If one were comparing just Diploprion with Grammistes, such a difference is evident, but it breaks down when other genera are considered. The interorbital of Aulacocephalus seems no more convex than that of Pogonoperca. Another distinction is the length of the "posterior process" of the premaxillary. This is reported as very long in the Diploprioninae but only moderate in length in the Grammistinae. If the posterior process of the premaxillary of KATAYAMA is the median ascending process, then again we fail to note any marked difference when all genera are compared. Diploprion has the longest process, but that of Aulacocephalus is only of moderate length; the distal end of the process of this genus does not approach the interorbital space whereas it enters the interorbital on all other grammistid genera (admittedly, this is due in part to the longer snout of Aulacocephalus).

As indicated in the Key to Genera below, there are some significant differences between the two genera Diploprion and Aulacocephalus and the other grammistids. These may well be regarded as of sufficient magnitude to warrant the recognition of a subfamily Diploprioninae. The genus Rypticus, on the other hand, is also very distinctive. If subfamilies are established, then this genus might also qualify as a separate subfamily.

The Indo-Pacific genera of Grammistidae are all monotypic, except for Diploprion with two species. By contrast, the genus Rypticus is represented by eight species in the Atlantic and three in the eastern Pacific (see further discussion under Rypticus).

There was no opportunity to test the possible toxic quality of the skin of the rare Australian fish Rainfordia opercularis MaCullogh which Schultz (1966) placed in 
the Grammistidae. A preserved specimen $96 \mathrm{~mm}$ in standard length (SL) from Heron Island, Great Barrier Reef was examined at the U. S. National Museum (USNM 203247). There is no suggestion of the thick whitish mucus so characteristic of grammistids on the specimen. Other features clearly separate this fish from the Grammistidae. The head is strongly depressed; there is no membraneous connection between the inner pelvic ray and the abdomen; there are two widely spaced dorsal fins; the preopercular margin is weakly serrate.

Rainfordia has also been regarded in recent classifications as a member of the Serranidae (Greenwood et al., 1966) and as a monotypic family (Norman, 1957; Woodland and Slack-Smith, 1963).

\section{KEY TO THE GENERA OF GRAMMISTIDAE}

1a. Scales mainly ctenoid, not embedded; preopercular margin strongly serrate; subopercle and interopercle partially serrate; nasal organ with lamellae arranged in a nearly complete circle; mucous cells stainable with Sudan Black $B$ present only in epidermis $\ldots \ldots \ldots \ldots \ldots \ldots \ldots$

1b. Scales cycloid, often embedded; preopercular margin smooth except for 1 to 4 spines on upper limb; subopercle and interopercle smooth; nasal organ vertically elongate, the lamellae horizontal; mucous cells stainable with Sudan Black B present in both the epidermis and in glands

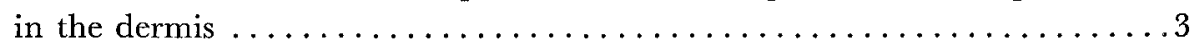

2a. Dorsal rays VIII, 13 to 16 ; anal rays II, 12 or 13 ; pelvic fins long, reaching posterior to anus; body very compressed, the width behind gill

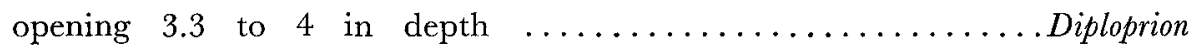

2b. Dorsal rays IX, 12; anal rays III, 9; pelvic fins not long, not reaching anus; body not very compressed, the width about 2.8 in depth . .Aulacocephalus

3a. No anal spines; anal soft rays 13 to 17 ; dorsal spines II to IV; dorsal soft rays 20 to 27 ; no deep notch between spinous and soft portions of dorsal fin; branched caudal rays 16 or 17 (usually 17); fins very fleshy; small embedded scales on interorbital space, snout below nostrils, maxillary, and more than half way out on fins $\ldots \ldots \ldots \ldots \ldots \ldots$ Ryticus

3b. Anal spines II or III (embedded in Grammistes); anal soft rays 8 or 9; dorsal spines VII; dorsal soft rays 12 to 14 ; a deep notch between spinous and soft portions of dorsal fin; branched caudal rays 15; fins not very fleshy (except basally); no scales on interorbital, maxillary or more

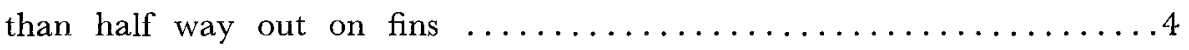

4a. No fleshy flap on chin; pectoral rays 14 or 15 ; dorsal soft rays 12 (rarely 13); first dorsal spine 1.2 to 1.5 in length of second dorsal spine; scales extending onto proximal portion of posterior dorsal and anal rays beyond basal scaly sheath $\ldots \ldots \ldots \ldots \ldots \ldots \ldots \ldots \ldots \ldots \ldots \ldots \ldots$ Grammistops 
4b. A fleshy flap on tip of chin; pectoral rays 16 to 18 ; dorsal soft rays 13 or 14; first dorsal spine about 1.7 in length of second dorsal spine; no scales extending beyond basal scaly sheath of dorsal and anal fins . . . . . . . 5

5a. Fleshy flap on chin large, about as long as eye diameter; anal rays III, 8

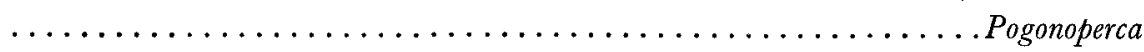

5b. Fleshy flap on chin very small; anal rays II, $9 \ldots \ldots \ldots \ldots$. $\ldots$ rammistes

\section{Diploprion bifasciatum}

\section{Figure 13}

Diploprion bifasciatum (Kuhl and van Hasselt) Cuvier and Valenciennes, 1828. Hist. Nat. Poissons, vol. 2, p. 137, pl. 21 (type locality, Java).

Diagnosis: Dorsal rays VIII,13 to 16 ; anal rays II,12 or 13; pectoral rays 17 or 18; lateral-line scales 80 to 88 ; vertical scale rows above lateral line to caudal base 100 to 110 ; scales on body ctenoid except those on nape, thorax, abdomen, and bases of dorsal and anal rays; no scales on interorbital, snout, or maxillary; gill rakers long, 9 to $10+20$ to 22 on first arch; body very deep, the depth 2 to 2.4 in standard length, and very compressed, the width behind gill opening 3.3 to 4 in greatest depth; head length 2.65 to 2.9 in standard length; mouth very oblique; preopercular margin coarsely serrate; subopercle and interopercle serrate; interorbital space strongly convex; pelvic fins very long, the tips extending posterior to spinous portion of anal fin; a deep notch between spinous and soft portions of dorsal fin; third dorsal spine the longest, its length 1.6 to 1.8 in head length; pale (light yellow in life) with two black bars, one on head through eye and a broader one on side of body.

Remarks: Diploprion bifasciatum is known from India and Ceylon through the IndoMalayan region and China to southern Japan. It is also recorded in Australia from Queensland to western Australia. It has not been taken from the islands of Oceania or from the western Indian Ocean. Kamohara (1961) illustrated a specimen which is $250 \mathrm{~mm}$ in total length. WEBER and DE BEAUfORT (1931) have recorded the total length as about $240 \mathrm{~mm}$. Roren (1963) stated that the species attains a maximum length of about 8 inches $(203 \mathrm{~mm}$ ) in the Gulf of Thailand.

Phillip C. Heemstra called our attention to an all-black specimen of D. bifasciatum $180 \mathrm{~mm}$ in standard length which was collected by Victor G. SPringer at One Tree Island, Great Barrier Reef. This specimen (USNM, uncatalogued) resembles D. bifasciatum in all respects except color. Two other specimens collected at the same island include a normal-colored individual of $153 \mathrm{~mm}$ standard length and one of $130 \mathrm{~mm}$ on which the black body bar encompasses nearly all of the posterior threefourths of the body. The latter specimen is thus somewhat intermediate in color to the black specimen and normal-colored individuals, therefore suggesting that the black is merely a melanistic form of bifasciatum. 
Hubss and CHU (1934) noted that the second and third dorsal spines of the late postlarval stage of this species are prolonged into filaments.

\section{Diploprion drachi EsTÈvE}

Figure 14

Diploprion drachi Estève in Roux-Estève and Fourmanoir, 1955. Ann. Inst. Océanogr. Paris, N. S. 30: 197 (type locality, Abulat, Red Sea).

Diagnosis: Dorsal rays VIII,15 or 16; anal rays II,12; pectoral rays 15 or 16; lateralline scales 87; vertical scale rows above lateral line to caudal base 113; scales ctenoid; no scales on interorbital, snout, maxillary or fins except basally on caudal fin; gill rakers $8+19$ or 20 ; body not very deep, the depth about 2.4 to 2.6 in standard length, and very compressed, the width behind gill opening 3 to 3.5 in depth; head length 2.6 to 2.8 in standard length; mouth very oblique; maxillary reaching posterior to center of eye; preopercular margin coarsely serrate; subopercle and interopercle serrate; interorbital space moderately convex; pelvic fins long, the tips reaching to or well beyond origin of anal fin; a deep notch between spinous and soft portions of dorsal fin; third dorsal spine the longest, its length 2.25 to 2.45 in head length (fin spines slightly abnormal in holotype); brown, the fins pale except spinous portion of dorsal fin and base of soft portion of dorsal fin which are black.

Remarks: Diploprion drachi was described from a single specimen $84 \mathrm{~mm}$ in standard length from the island of Abulat in the Red Sea. This fish was kindly sent on loan by M. L. Bauchot of the Muséum National d'Histoire Naturelle. The most obvious differences between it and Diploprion bifasciatum are less body depth for drachi, fewer pectoral rays (15 or 16 for drachi, 17 or 18 for bifasciatum), and color. D. drachi lacks the blackish bars of bifasciatum, but it has a nearly black spinous dorsal fin, and the base of the soft portion of the fin is also blackish.

Victor G. SPRINGer of the U. S. National Museum recently collected a specimen of $D$. drachi (USNM 205489, $108 \mathrm{~mm}$ SL) in the Strait of Jubal, Red Sea (southern end of Sinai Peninsula at Ras Muhammad) at a depth of 30 feet. The specimen was sent on loan, and its descriptive data are incorporated into the diagnosis above.

\section{Aulacocephalus temmincki}

Figure 15

Aulacocephalus temmincki Blezker, 1857. Verh. Bat. Gen., vol. 26, p. 15, pl. 5, fig. 2 (type locality, Nagasaki, Japan).

Diagnosis: Dorsal rays IX,12; anal rays III,9; pectoral rays 14 to 16 ; lateral line scales 76 to 82 ; vertical scale rows above lateral line to caudal base 83 to 87 ; scales ctenoid; no scales on interorbital, snout, maxillary, or fins except basally on caudal; 
gill rakers 7 to $8+18$ to 20 ; depth of body about 2.9 to 3 in standard length and width of body behind gill opening about 2.8 in depth; head length 2.4 to 3 in standard length; snout relatively long, its length about 2.7 in head length; mouth slightly oblique; preopercle coarsely serrate; subopercle and interopercle serrate; interorbital space moderately convex; pelvic fins inserted beneath pectoral fins, not very long (about 2 in head), the tips not reaching anus; third and fourth dorsal spines the longest, their length 3.1 to 3.5 in head; first and last dorsal spines subequal, about half the length of longest spines; color in life deep blue with a bright yellow band running from near front of upper jaw through eye, along upper part of back and basally in dorsal fin to upper base of caudal fin; a spot of yellow at lower base of caudal fin and a streak of yellow along upper part of maxillary; soft portions of median fins with black rays and translucent membranes.

Remarks: In the Proceedings of the Zoological Society of London (1833, pt. 1, p. 117) there is an anonymous report of ichthyological contributions from Mauritius which includes the statement, "M. LIÉNARD, sen., has described a new species of Grammistes, Cuv., distinguishable from the two previously known by its compressed form, on which account it has been designated Gramm. compressus: its first dorsal fin has nine rays." Boulenger (1895) placed this name with a question mark at the head of his list of synonymy for Pogonoperca ocellata. We have been unable to find any publication by LIÉNARD in which Grammistes compressus is formally described. If nine rays can be construed as meaning nine dorsal spines, there is a possibility that compressus could be $A$. temmincki, since it is the only known grammistid with nine dorsal spines. However, $G$. compressus cannot be positively identified from the sparse descriptive data given, and we propose that this name be suppressed.

Aulacocephalus temmincki is one of the most strikingly colored of all the serranoid fishes. It has an unusual disjunct distribution: Japan, northeastern China and Korea (Reeves, 1927), Natal coast of South Africa (Gilchrist and Thompson, 1917), Mauritius (Günther, 1859), Thailand (Boulenger, 1895), Kermadec Islands (WaIte, 1911), and New Zealand (Whitcey, 1968). In his The Sea Fishes of Southern Africa, Sмітн (1949) referred to this species as unmistakable and reported it as occurring as far south as Durban. He also stated that it has excellent flesh and attains 14 inches $(356 \mathrm{~mm})$ in length. The senior author has examined a specimen $178 \mathrm{~mm}$ SL from Taiwan at the University of Tokyo (No. 22615). With the exception of Thailand, these localities lie within the range in latitude of about $20^{\circ}$ to $36^{\circ}$.

Suspecting that there might be some error in Boulenger's Thailand record, which was based on a skeleton of a half-grown fish, we wrote A. C. WHeEler of the British Museum (Natural History). He confirmed the identification and noted that the label with the skeleton reads, "Siam Purchd. of Mr. Jamracin". He added, "JAmracin was a general dealer in natural history items, and as such his localities may be open to more suspicion than those of a collector from an area." This skeleton represents the only record of the species from a truly tropical locality. If $A$. temmincki could exist in 
a region where the seas remain warm throughout the year, it is difficult to understand why it has not been recorded from areas such as the East Indies or Philippines. It would seem more reasonable to assume that JAMRACH's specimen came from a cooler locality than Thailand than to explain the apparent absence of this fish from tropical localities intermediate within its present range. Perhaps this species lived in the lower latitudes at some time in the past when seas were cooler, as during an ice age. It is also possible that it will be found in tropical regions in deeper water.

\section{Genus Rypticus}

Diagnosis: Dorsal spines II to IV; dorsal soft rays 20 to 27 ; no anal spines; anal soft rays 13 to 17 ; pectoral rays 13 to 17 ; branched caudal rays 16 or 17 (usually 17 ; other genera with 15); vertical scale rows above lateral line to caudal base 75 to 130 (from Schultz and Reid, 1939); scales cycloid, embedded, present on interorbital, side of snout below nostrils, maxillary, and more than half way out on fins; fullyformed gill rakers of adults not numerous, the total count 5 to 11 on first arch; body moderately elongate and compressed; head moderately pointed, the length 2.4 to 3.4 in standard length; mouth large and oblique, the maxillary usually reaching to or beyond a vertical at posterior edge of eye; opercular spines 3 (except $R$. randalli with 2); preopercular margin smooth except 1 to 3 spines on upper portion; subopercle and interopercle smooth; interorbital space narrow, nearly flat to moderately convex; pelvic fins small, their length contained more than 3 times in head length; fins fleshy; no deep notch between spinous and soft portions of dorsal fin; dorsal spines short; color drab-gray, brown, or olivaccous, some species marked with dark or light spots.

Remarks: Courtenay (1967) has revised the Atlantic species of Rypticus. He recognized the following eight species: saponaceus (BLOaH and SAHNEIDER), subbifrenatus Gill, macrostigmus Courtenay, bistrispinus (Mitchill), bornoi Beebe and Tee Van, maculatus Holbrook, randalli Courtenay, and brachyrhinus Courtenay. All occur in the western Atlantic and one of them, saponaceus, is found also at St. Helena, Ascension, the Cape Verde Islands, and the coast of Africa from Senegal to the Congo. R. maculatus occurs from southern Florida to Cape Hatteras and in the northern Gulf of Mexico. The other species are more tropical in their distribution.

Boyd W. Walker and George G. Williams have worked on the eastern Pacific species of Rypticus but have not yet published their findings. Walker (personal communication) informed us that he and Williams will recognize bicolor (VALENCIENNEs) and nigripinnis Gill. In addition they have an undescribed species from the Revillagigedo Islands.

The species of Rypticus range in size from the small bornoi (still known only from the type from Haiti which measures $49.4 \mathrm{~mm}$ standard length) and macrostigmus (the twelve recorded specimens from the Bahamas and Panama are 40 to $57 \mathrm{~mm}$ in standard 
length) to saponaceus as large as $258 \mathrm{~mm}$ standard length and bicolor to about $250 \mathrm{~mm}$ standard length.

RANDALL (1967) reported that 12 of 27 West Indian specimens of saponaceus with food in their stomachs fed about equally on fishes and crustaceans, and Hobson (1965, 1968) found that 13 individuals of bicolor from the Gulf of California fed mainly on benthic crustaceans. Both of these species are primarily nocturnal. It is expected from observations of the secretive behavior of other species of grammistids during daylight hours that they will prove to be principally nocturnal also.

For the analysis of the skin toxin of Rypticus we obtained fresh material of the following species: saponaceus, subbifrenatus, randalli, and bicolor. Photographic illustrations are presented of these (Figs. 16 to 19 ).

\section{Grammistops ocellatus}

Figure 20

Grammistops ocellatus Schultz in Schultz et al., 1958. Bull. U.S. Natl. Mus. 202, vol. 1, p. 386, fig. 62 (type locality, Bikini Atoll, Marshall Islands).

Diagnosis: Dorsal rays VII,12 (one with VI,13); anal rays III,9 (one with 8); pectoral rays 14 or 15; lateral-line scales 58 to 67 ; vertical scale rows above lateral line to caudal base 82 to 100 ; scales cycloid, embedded, none on interorbital, snout, or maxillary; fins scaled basally, those on caudal reaching about half way to edge of fin; scales extending onto proximal portion of posterior 7 or 8 dorsal rays and 3 or 4 anal rays beyond the scaled basal sheath; gill rakers 1 or $2+6$ to 9 on first arch (plus 5 to 7 low tubercles on upper limb and 4 to 8 on lower); body moderately elongate, the depth 3.1 to 3.7 in standard length, and moderately compressed, the width behind gill opening about 2 in depth; head length 2.55 to 2.65 in standard length; mouth large and oblique, the maxillary reaching to or beyond hind margin of eye; ventral profile of head jutting below that of thorax; preopercular margin smooth except for 1 or 2 short broad-based spines on upper margin (absent from one side of two specimens); subopercle and interopercle smooth; pelvic fins 2.1 to 2.2 in head length; fins not fleshy except basally; dorsal fin nearly notched or just notched to base between spinous and soft portions; dorsal spines short, the second or third the longest, 3.4 to 4.4 in head length; first dorsal spine 1.2 to 1.5 in second dorsal spine; color gray-brown, the head yellowish in life, with a prominent dark ocellus nearly as large as eye on opercle (one Tahitian example with a group of three small ocelli at this location); a dark brown spot near tip of lower jaw on each side; front edge of eye narrowly blackish; membranes of fins pale except basally, the rays dark.

Remarks: Grammistops ocellatus is known in the literature from the type specimen, $85.5 \mathrm{~mm}$ in standard length taken in 20 to 40 feet in the Marshall Islands, and two specimens, 63 and $88 \mathrm{~mm}$ in length, from 12 to 60 feet off East Africa $\left(5^{\circ} \mathrm{S}\right.$ and $14^{\circ}$ 
$\left.10^{\prime} \mathrm{S}\right)$. The African specimens were described as Tulelepis canis by Smiтh (1954); this name was correctly referred to the synonymy of $G$. ocellatus by GosLine (1960).

We here record the species from Tahiti (BPBM 8330: 2 specimens, 88 and 107 mm SL), Guam (BPBM 9021: 1 specimen, 94 mm SL), and Palau (BPBM 9556: 1 specimen, $75 \mathrm{~mm}$ SL). The Tahitian specimens were collected by the senior author from a cave in a coral reef at a depth of 50 feet in Popote Bay, district of Papara on March 6, 1969. The Guam specimen was taken in 10 to 26 feet by Harry T. KamI on December 6, 1969. The Palauan specimen was collected by the senior author, A. R. Emery, and E. S. Helfman in a cave in 60 feet near the entrance to Malakal Pass on April 17, 1970. Further collecting in the tropical Indo-Pacific will no doubt further reduce the present discontinuities in the distribution of this rare species.

\section{Pogonoperca punctata}

Figure 21

Grammistes punctalus Guvier and Valenciennes, 1830, Hist. Nat. Poiss., vol. 6, p. 504 (type locality, South Seas, near Vanikoro Islands).

Diagnosis: Dorsal rays VIII, 12 or 13 (reports of VII are probably due to overlooking the small eighth spine); anal rays III,8; pectoral rays 17 or 18; lateral-line scales 59 to 70 ; vertical scale rows above lateral line to caudal base about 88 ; scales cycloid, embedded, none on interorbital, snout, maxillary, or fins except basal fleshy portion of dorsal and anal fins, basal two-fifths of caudal fin, and basal part of paired fins; gill rakers shorter than longest gill filaments, with 1 or $2+7$ or 8 fully formed on first arch (plus about 7 low tubercles on both upper and lower limb of arch); a prominent flat fleshy protuberance about as large in area as eye oriented transversely at tip of chin; body oblong, the depth 2.2 to 2.7 in standard length, and compressed, the width behind gill opening 2.2 to 2.7 in depth; head length 2.5 to 2.75 in standard length; mouth moderately large and very oblique, the maxillary nearly reaching or extending slightly posterior to a vertical through center of eye; preopercle with 3 to 5 short spines on upper margin; subopercle and interopercle smooth; interorbital moderately convex; length of pelvic fins 1.7 to 2 in head length; fins not fleshy except basally; a deep notch nearly separating spinous and soft portions of dorsal fin; second or third dorsal spines the longest, 2 to 3 in head length; first dorsal spine 1.6 to 2.1 in length of second dorsal spine; color brown, a little blotchy, with numerous small dark-edged white spots (smaller dorsally than ventrally) on head, body, chin flap, basally on fins and extending part way out on soft rays (some areas on side of body with fewer or almost no white spots); four triangular black saddles on back, the largest on nape, the next largest beneath spinous portion of dorsal and extending as a broad blackish area into fin, covering most of the second and third interspinous membranes (rest of spinous portion of fin with white spots as on body); third black saddle beneath middle-anterior part of soft portion of dorsal fin and the last, about 
as large as eye, on front of caudal peduncle; in addition there is a round black spot about the size of the pupil on upper middle base of caudal fin, another at midbase of anal fin, and a third at origin of anal fin; a fourth black spot about twice the diameter of the previous spots lying midventrally in front of anus; a blackish zone across upper interorbital and extending as a diffuse bar below eye (unlike other black areas, this contains faint white dots); soft portions of fins with membranes pale and rays dark except for the previously mentioned white basal spots.

Remarks: Cuvier and Valenciennes based their description of Grammistes punctatus on a drawing by MerTens of a 7-inch $(177.8 \mathrm{~mm}$ ) fish from "la mer du Sud, prés de Vanicolo" (Vanikoro Islands). , There is no type specimen.

GüNTHer (1859) described Pogonoperca ocellata from a dried specimen 12 inches (304.8 mm) long from a locality unknown to him. In the same work he recognized Grammistes punctatus Guvier and Valenciennes. Boulenger (1895) placed G. punctatus in Pogonoperca and gave its distribution as the Malay Archipelago and Polynesia. He ascertained that the type locality of ocellata is Mauritius and listed other specimens from the Seychelles and Madras, India. He stated that ocellata is "very closely allied" to punctata, differing in the more elongate body (depth 2.5 to 2.75 in total length, as opposed to 2.25 to 2.33 for punctata), a shorter head (length 3.0 to 3.5 times in total length, as opposed to 2.8 to 3.0 for punctata), and white spots more numerous and entirely covering the fins.

BLiss (1883) described Pogonoperca reticulatus (attributing the name to SteinDAGHNER, MS) from a specimen $190 \mathrm{~mm}$ in standard length from Mauritius. This specimen was examined at the Museum of Comparative Zoology at Harvard University (MCZ 5933). The depth of the body is 2.7 in the standard length, and the head length 2.5 in the standard length. The fins are covered with relatively large close-set pale spots. In addition, the dark areas on the back are not as well developed, and no obvious black pigment extends into the spinous dorsal fin. There is no black spot at the base of the caudal fin, nor are any visible at the origin or mid-base of the anal fin. All of the meristic data of this fish match that of Pacific specimens. A figure of a 9-inch $(228.6 \mathrm{~mm}$ ) specimen from the Seychelles in Sмгтн and Sмгтн (1963) also reveals white spots running to the periphery of the fins. From the illustration the depth of the body appears to be about 2.3 in the standard length and the head about 2.7 in the standard length.

More specimens of Pogonoperca are needed to more fully document the differences between Indian Ocean and Pacific Ocean fishes of this genus. We do not believe, however, that these differences are specific in magnitude. Therefore we provisionally refer ocellata and reticulatus to the synonymy of punctata.

Judging from the few records in the literature and paucity of specimens in museums, Pogonoperca punctata is not a common species. In addition to the localities mentioned above, it is reported from Ambon (Bleeker, 1857), Ulea (Caroline Islands) (KItTlitz, 1858), Society Islands (GüNTher, 1873), Réunion and Madagascar 

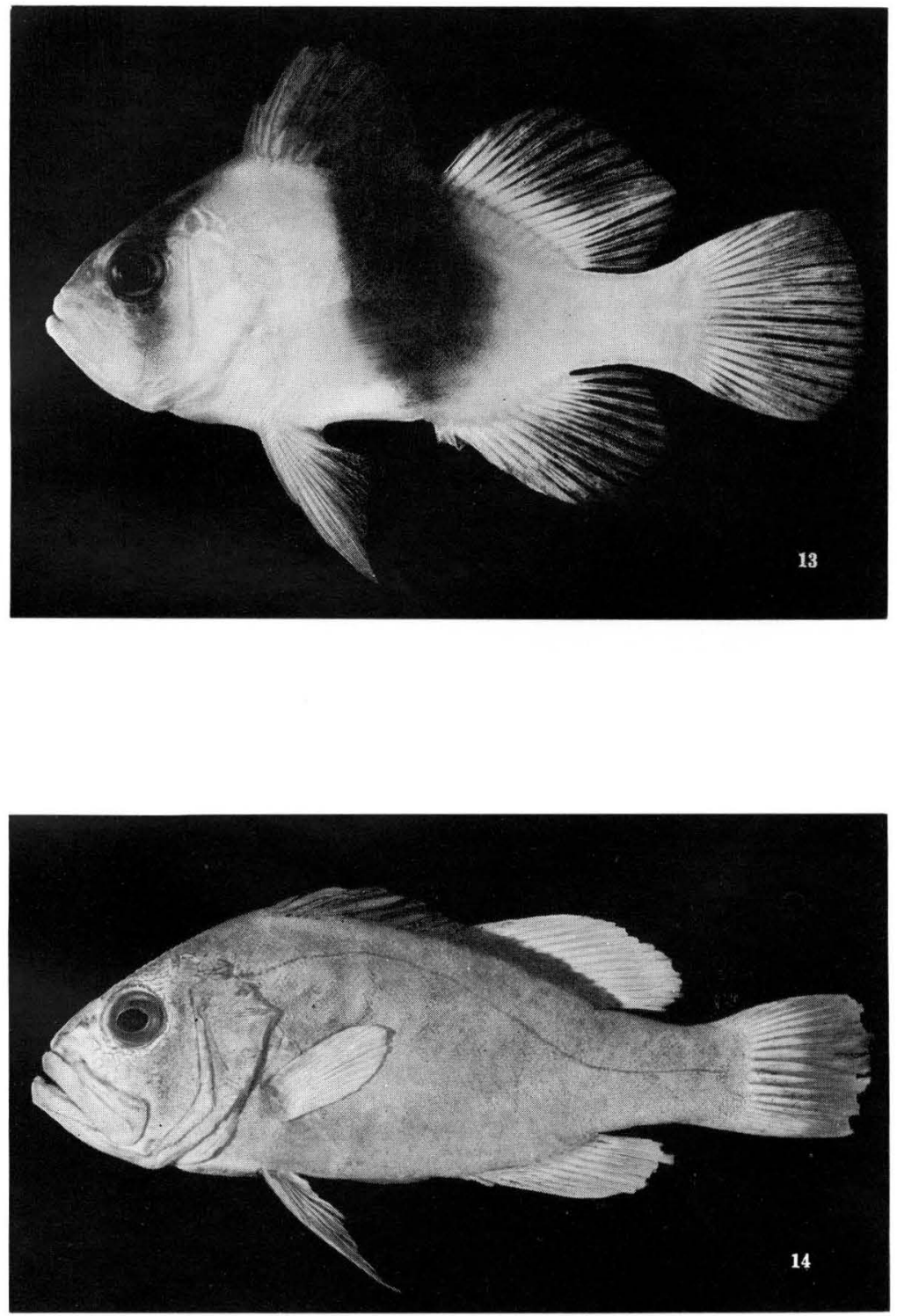

Figure 13. Diploprion bifasciatum, $67 \mathrm{~mm}$ SL, Philippine Islands.

Figure 14. Diploprion drachi, holotype, $84 \mathrm{~mm}$ SL, Abulat, Red Sea. 

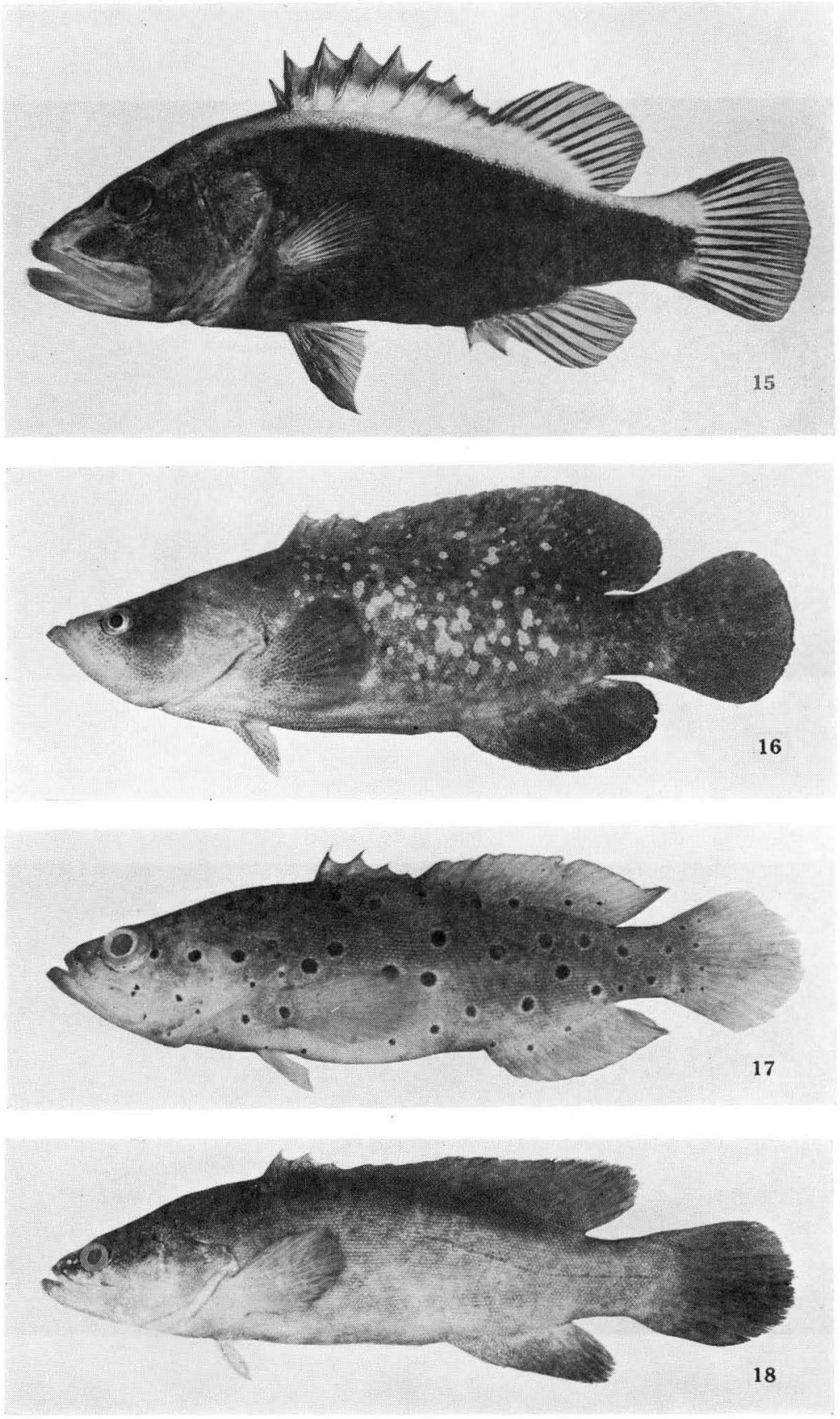

Figure 15. Aulacocephalus temmincki, $147 \mathrm{~mm}$ SL, Shirahama, Japan.

Figure 16. Rypticus saponaceus, $127 \mathrm{~mm} \mathrm{SL}$, St. John, U. S. Virgin Islands.

Figure 17. Rypticus subbifrenatus, $63 \mathrm{~mm} \mathrm{SL}$, Puerto Rico.

Figure 18. Rypticus randalli, $127 \mathrm{~mm}$ SL, Puerto Rico. 

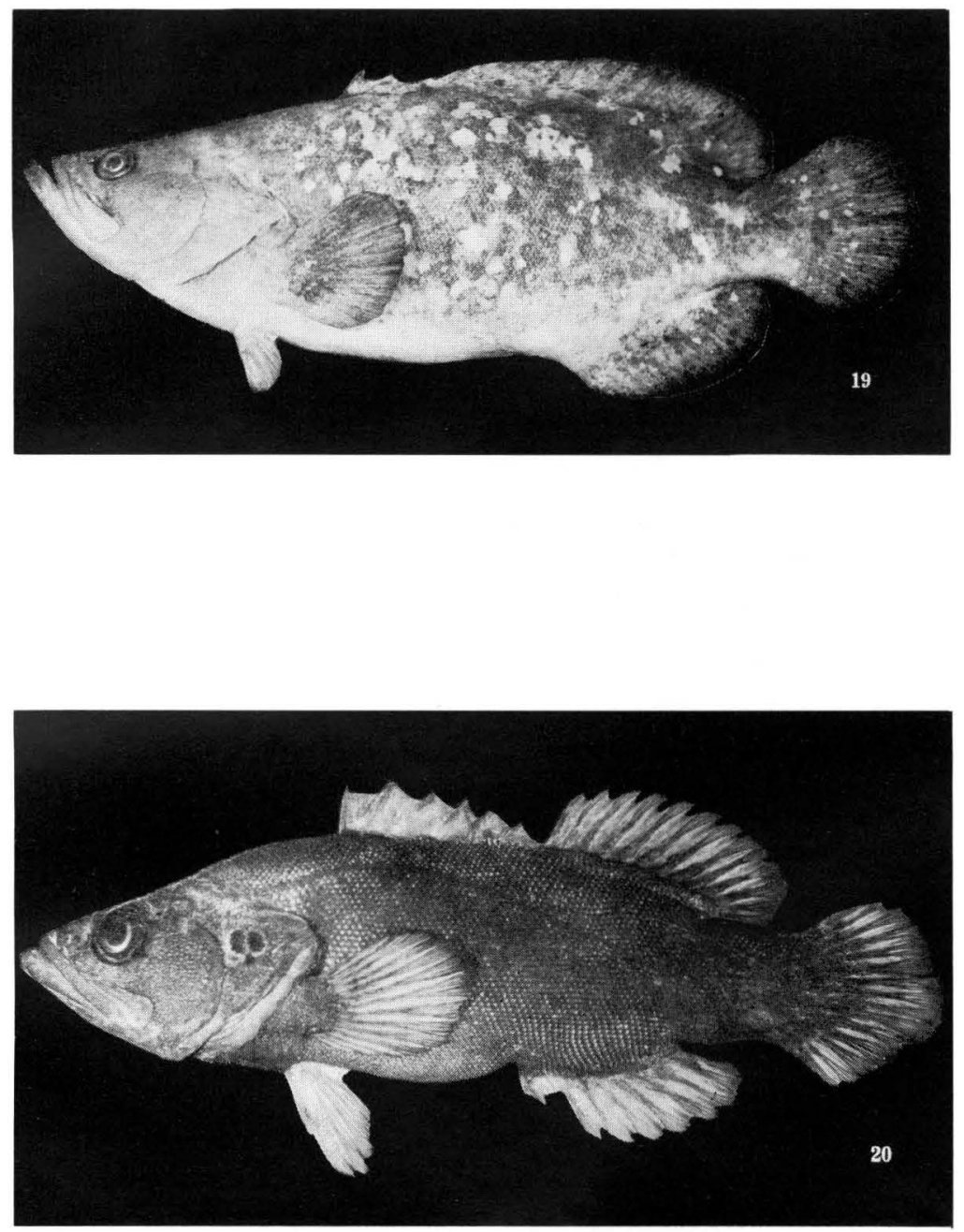

Figure 19. Rypticus bicolor, $199 \mathrm{~mm}$ SL, Isla Las Animas, Gulf of California.

Figure 20 Grammistops ocellatus, $112 \mathrm{~mm}$ SL, Tahiti. 

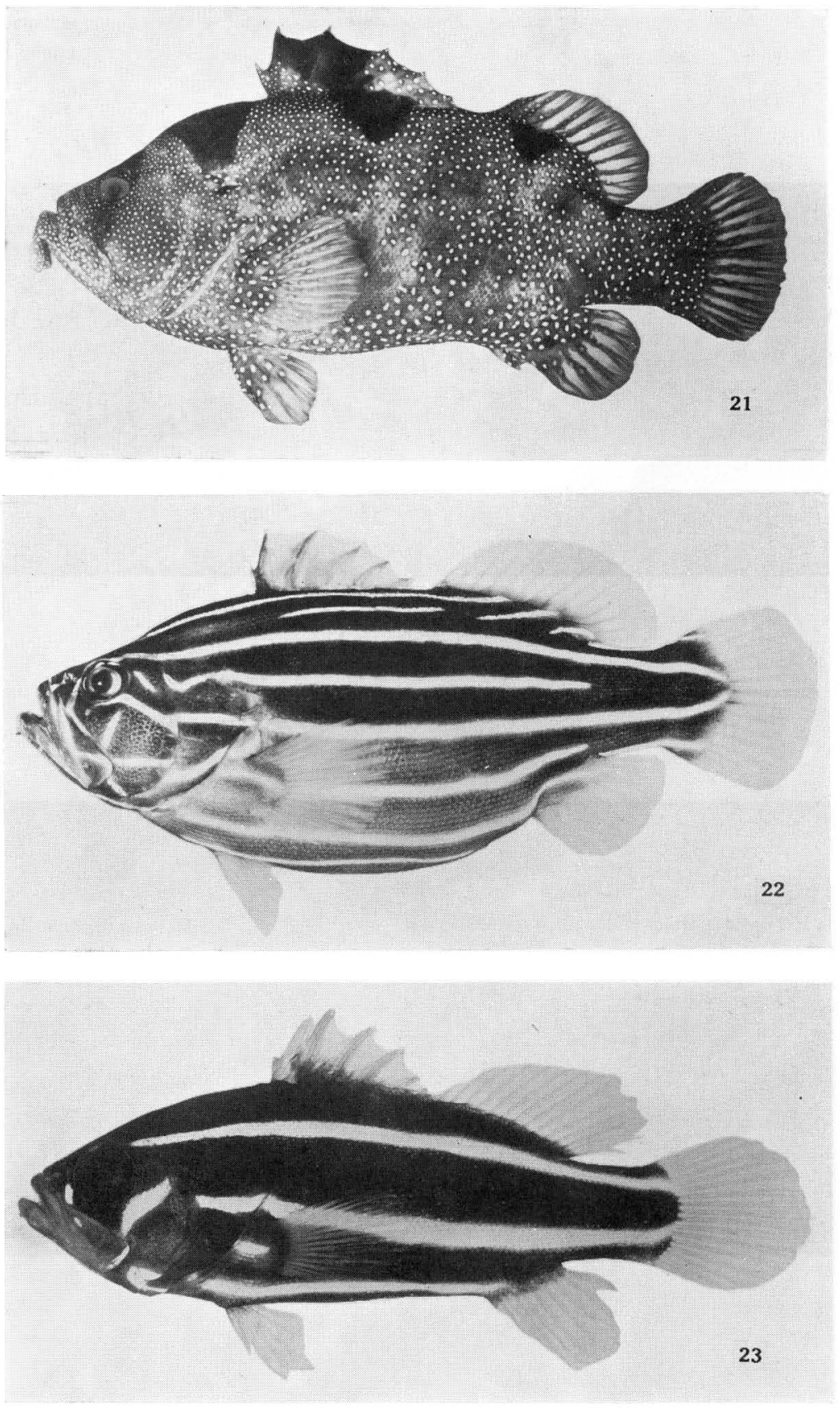

Figure 21. Pogonoperca punctata, $173 \mathrm{~mm} \mathrm{SL}$, Washington Island, Line Islands.

Figure 22. Grammistes sexlineatus, $75 \mathrm{~mm}$ SL, Guam. Abdomen distended from a half-digested fish (about $45 \mathrm{~mm}$ in SL and $10 \mathrm{~mm}$ in depth) in stomach.

Figure 23. Grammistes sexlineatus, $34 \mathrm{~mm}$ SL, Eniwetok Atoll, Marshall Islands. 
(Bleexer, 1874), Misol and Seychelles (Boulenger, 1895), Nauru (Whitley and Colefax, 1938), Japan (Katayama, 1960b and Kamohara, 1962), and the Ryukyu and Amami Islands (Hashimoto and Kamiya, 1969).

We record the species herein from Jarvis Island $\left(1^{\circ} 55^{\prime} \mathrm{N} ; 157^{\circ} 20^{\prime} \mathrm{W}\right)$ and Washington Island $\left(4^{\circ} 43^{\prime} \mathrm{N} ; 160^{\circ} 26^{\prime} \mathrm{W}\right)$ in the Line Islands. The Jarvis record is based on a specimen (USNM 205492, $148 \mathrm{~mm} \mathrm{SL}$ ) collected by F. Sibley in a channel on the SW side of the island at a depth of 10 feet on November 18, 1964. The Washington specimen (BPBM 7746, $173 \mathrm{~mm} \mathrm{SL}$ ) was collected off the west side of the island from beneath a small ledge in 55 feet by the senior author and $\mathrm{J}$. McVey on November 3, 1968.

A second specimen of Pogonoperca punctata at the Museum of Comparative Zoology (MCZ 25771, $158 \mathrm{~mm}$ standard length) collected by Andrew Garretr bears the label Sandwich Islands (=Hawaiian Islands). There is no date of collection. In spite of intensive fish collecting in the Hawaiian Islands since GaRRETT's time, no additional specimens of Pogonoperca have been obtained. GARretr collected numerous fishes elsewhere in the Pacific, especially in French Polynesia, and there is a strong possibility of locality error for the Hawaiian record.

Our largest specimen (from Okinawa) measured $300 \mathrm{~mm}$ in total length (about $250 \mathrm{~mm} \mathrm{SL}$ ) and weighed $510 \mathrm{~g}$. BOuleNGer reported the total length of his largest specimen (under the name $P$. ocellata) as $330 \mathrm{~mm}$.

\section{Grammistes sexlineatus}

Figures 22 and 23

Perca sexlineata Thunberg, 1792. Vet. Akad. Nya Handl., vol. 13, p. 142, pl. 5 (type locality, East Indies).

Diagnosis: Dorsal rays VII,13 or 14; anal rays II,9; pectoral rays 16 to 18 ; lateralline scales 60 to 72 ; vertical scale rows above lateral line to caudal base 82 to 88 ; scales cycloid, embedded, none on interorbital, snout, maxillary, or fins except basal fleshy portion of dorsal and anal fins, basal half of caudal fin, and basal part of paired fins; gill rakers shorter than longest gill filaments, with 1 to $3+7$ to 9 fully formed on first arch (plus 4 to 6 low tubercles on upper limb and 4 to 7 on lower); a small fleshy flap (smaller than pupil of eye) on tip of chin; body oblong, the depth 2.3 to 2.8 in standard length, and compressed, the width 2 to 2.7 in depth; head length 2.3 to 2.7 in standard length; mouth large and very oblique, the maxillary reaching from posterior to center of eye to slightly beyond eye; upper preopercular margin with 2 to 4 short broad-based spines; subopercle and interopercle smooth; interorbital slightly to moderately convex; pelvic fins 1.8 to 2.5 in head length; fins not fleshy except basally; a deep notch nearly separating spinous and soft portions of dorsal fin; third (rarely the second) dorsal spines the longest, 2.9 to 3.4 in head length; first dorsal spine 1.7 to 2 in second; color dark brown with light yellow stripes; fin 
rays of median fins pink to reddish brown, the membranes pale. Juveniles up to about $50 \mathrm{~mm} \mathrm{SL}$, such as the one of Figure 23, have three yellow stripes on the side, one from behind upper eye to upper base of caudal fin, one from opercle running above pectoral base to lower base of caudal fin, and the third along lower chest and abdomen; in addition there is a median yellow band from snout to origin of dorsal fin and prominent yellow markings on head; there is a small black spot at front of upper lip. With increasing size, secondary yellow stripes appear in the dark brown zones between the yellow stripes, the first on the side of nape, running to beneath the soft portion of the dorsal fin; these stripes develop from the anterior part of fish and are narrower than the initial three stripes. By a length of about $75 \mathrm{~mm}$ the stripes are complete, resulting in six on a side (not including median dorsal band on head and nape), but with the original stripes still wider. With increasing size, the stripes become equal in width and two more may be added, as shown in Figure 22. In large adults the yellow stripes break up into series of dashes.

Remarks: This species has often been recorded under the name Grammistes orientalis Bloch and Sahneider (1801). Three other synonyms have long been recognized, vittata, triacantha and pentacantha, all described by LACÉPÈDE (1802).

Arnoult in Arnoult, Bauchot-Boutin, and Roux-Estève (1958) named Grammistes lineatus as new from the island of Aldabra in the Indian Ocean. The description, which was based on a single specimen $46 \mathrm{~mm}$ in total length, and the figure strongly suggest that $G$. lineatus is a juvenile of $G$. sexlineatus. The specimen has three pale stripes on the body as may be seen on Fig. 23 herein of $G$. sexlineatus, a specimen of about the same size (the stripes are broader on lineatus, but we have other specimens of sexlineatus which have stripes this broad). The only significant difference between lineatus and sexlineatus appeared to be the dorsal ray count of VI,7 for the former. Oddly, this was not mentioned specifically by ARNoult as a distinction between the species. M. L. Bauchot examined the holotype for us at the Muséum National d'Histoire Naturelle in Paris. She reported that the dorsal rays are VII,13. Therefore we refer $G$. lineatus to the synonymy of $G$. sexlineatus.

Fowler (1946) described a new subspecies, Grammistes sexlineatus proerythraeus, from a single specimen $33 \mathrm{~mm}$ in total length from the Ryukyu Islands. He distinguished it by the scarlet front of the spinous dorsal fin. Kamohara (1964) recognized the subspecies, giving its range as Kochi Prefecture, Japan, and Ryukyu Islands. He recorded the range of Grammistes sexlineatus sexlineatus as Mie Prefecture, Japan to the Red Sea; Africa; Australia and Polynesia. Such a distribution for two subspecies is illogical. More important, the distinction given by FowLeR is probably normal juvenile coloration for the species. The specimen of Figure 23, $34 \mathrm{~mm}$ in standard length and $43 \mathrm{~mm}$ in total length, from Eniwetok, Marshall Islands, had a dorsal fin which was bright red in life anterior to the second dorsal spine; this color extended onto the basal portion of the second interspinous membrane; therefore, there seems to be no justification for the subspecific differentiation as proposed by FowLER. 
Grammistes sexlineatus has the broadest distribution of any species of soapfish. It is recorded from east Africa as far south as Durban (by Ммiтн, 1949, who noted that the flesh is bitter) to the islands of eastern Oceania except Hawaii and Easter Island. It is known from western and northern Australia, and ranges north to southern Japan. The Bishop Museum has specimens from the Philippines, Palau Islands, Solomon Islands, Guam, Marshall Islands, Marcus Island, Fiji, Samoa, Society Islands, and Tuamotus. Sмгтн (1949) stated that the species attains 10 inches $(254 \mathrm{~mm})$. Our largest specimen measured $144 \mathrm{~mm}$ in total length (about 5.7 inches); it weighed 64 grams. Mr. S. Mrkami of the aquarium at Yomiuriland, Japan informed us that he has a preserved specimen which is $270 \mathrm{~mm}$ (10.6 inches) in total length.

\section{Summary}

A toxin in the mucus of soapfishes (Grammistidae) has been detected by a number of methods, including its distinctive bitter taste. It is present to a varying degree in all the genera. By the taste test Grammistes and Pogonoperca gave the strongest reaction, Aulacocephalus and Diploprion an intermediate reaction, and Grammistops and Rypticus the weakest. The skin toxin appears to be completely lacking in the related families Serranidae and Pseudogrammidae.

The amount of toxin secreted increases when a fish is frightened. Other fishes confined in a small volume of water with a soapfish under stress soon die. Previous investigations have revealed that soapfish toxin is lethal to mammals when force-fed in capsules or injected. The symptoms in cats show some similarity to ciguatera.

The toxin causes hemolysis of mammalian blood cells. Through tests of hemolytic activity on rabbit blood cells it was shown that the soapfish mucus alone contains much more toxin than ground skin tissue. Judging from hemolysis, the toxin of Grammistes sexlineatus and Pogonoperca punctata is more concentrated than that of other soapfishes. Taste tests also indicate that these two species have a strong toxin.

When equivalent amounts of toxin (as determined by hemolytic activity) from a species of each of the six grammistid genera were dissolved in water for the determination of ichthyotoxic activity, it was noted that the death time of the test fish, Oryzias latipes, was nearly the same for all preparations.

The principal function of the toxin would seem to be defensive. When a lionfish (Pterois volitans) was fed a small live Grammistes sexlineatus in an aquarium, it quickly expelled the soapfish and made no further attempt to feed upon it.

Chemical properties of the toxin, drawing in part on Наsнimoto and КамтуA (1969), are as follows: insoluble in diethyl ether, petroleum ether, and chloroform; partially soluble in water, physiological saline, $10 \%$ acetic acid and hot ethanol; effectively soluble in hot $70 \%$ ethanol, $n$-butanol, and $n$-amyl alcohol. In an alkaline medium ( $\mathrm{pH} \mathrm{12)} \mathrm{the} \mathrm{toxin} \mathrm{is} \mathrm{not} \mathrm{heat} \mathrm{stable,} \mathrm{but} \mathrm{no} \mathrm{loss} \mathrm{of} \mathrm{activity} \mathrm{takes} \mathrm{place} \mathrm{when}$ heating in an acid medium ( $\mathrm{pH} 2)$. Dialysis carried out at $5^{\circ} \mathrm{G}$ for 5 hours resulted 
in $35 \%$ of the activity in the outer solution.

Thin-layer chromatograms from the preparations of toxin for hemolytic activity were similar for the six species tested. Spraying the cellulose plate with $2 \%$ rabbit blood cell suspension revealed 4 or 5 toxic components. These were almost the same as those positive to the Dragendorff reagent.

Further purification was carried out for the toxin of Grammistes sexlineatus, Pogonoperca punctata and Rypticus saponaceus by silicic acid column chromatography. Each preparation consisted of a peculiar peptide with a moiety of tertiary or quarternary amine. The total nitrogen varied from 8.8 to $12.7 \%$, and amino acid nitrogen from 54 to $91 \%$. The four dominant amino acids of the toxin of all three species are leucine, isoleucine, phenylalanine, and glycine.

The differences in the composition of amino acids and the ultraviolet and infrared spectra among the species may be due to differences in purity of the preparations. In view of the many similarities, we believe the toxin, which we name grammistin, to be the same or very similar throughout the family Grammistidae.

Histological preparations of the skin of soapfishes revealed two types of mucous cells in the epidermis, one like that found in fishes in general, and the other which was negative to PAS reaction but positive to Sudan Black B staining. In addition, for all the species tested except Diploprion bifasciatum and Aulacocephalus temmincki, there are multicellular glands in the dermis between the scales which stain with Sudan Black B and have ducts that lead to the surface. Grammistin also stains black with the same reagent.

The soapfishes have generally been regarded as a subfamily, at best, of the Serranidae in the older literature. GosLine (1960) proposed that they be classified as a separate family, the Grammistidae, but he included the pseudogrammids, excluded Diploprion, and did not consider Aulacocephalus. Schultz (1966) recognized the family Grammistidae, included the genera Diploprion and Aulacocephalus, added Rainfordia and retained the pseudogrammids. Nevertheless, he expressed doubt of the validity of the family, stating that the only character common to all grammistid genera and not the Serranidae is the membraneous attachment of the inner pelvic ray to the body.

We can exclude Rainfordia on morphological grounds from the Grammistidae. The pseudogrammids, with an incomplete lateral line (and for some a secondary lateral line), 26 to 28 vertebrae, and scales of moderate size, might also be separated on morphology alone. One additional character, a heavy coat of mucus containing the skin toxin grammistin serves to distinguish the Grammistidae from both the Serranidae and the Pseudogrammidae.

We recognize six genera in the Grammistidae. Of these, Diploprion and Aulacocephalus appear to be more closely related to the Serranidae than the other grammistid genera. They stand apart morphologically from the rest of the grammistids in their possession of ctenoid scales, a nasal organ with the lamellae arranged as radii of a 
circle, a strongly serrate preopercle, and some serrations on the interopercle and subopercle.

Diploprion is characterized by a dorsal fin formula of VIII,13 to 16 and pelvic fins which reach posterior to the anus. It is represented by two species, the deepbodied $D$. bifasciatum which is light yellow with two broad black bars, and $D$. drachi with less body depth and no black bars. The latter is known from only two specimens from the Red Sea; additional descriptive data are presented for it, and it is illustrated for the first time. D. bifasciatum ranges from India through the Indo-Malayan region to China and Japan.

Aulacocephalus is represented by one species, temmincki, which is bright blue with a yellow stripe running from the snout through the eye and along the upper back; its dorsal rays are IX,12. With the exception of a dubious record from Thailand, the distribution of this fish consists of the western Pacific and Indian Oceans between latitudes $20^{\circ}$ to $36^{\circ} \mathrm{N}$ and $\mathrm{S}$.

Rypticus is a distinctive genus which lacks anal spines, has II to IV dorsal spines and 20 to 27 rays, and 16 or 17 (instead of 15) caudal rays. Courtenay (1967) revised the eight Atlantic species; in addition, three are known from the eastern Pacific (one of which is undescribed); none are colorful.

Also drab is Grammistops ocellatus, named for the dark ocellus on the opercle. It has a dorsal formula of VII,12 (rarely VI,13). It was described from one specimen from the Marshall Islands and recorded since from two specimens from East Africa. The range is here extended to include Palau, Guam, and Tahiti.

Pogonoperca appears to be monotypic. We regard $P$. ocellata GüNTHER and $P$. reticulatus Steindachner (in Bliss) as probable synonyms of $P$. punctata (Guvier and Valenciennes). This fish is characterized by a large fleshy flap on the tip of the chin, dorsal rays VIII,12 or 13; anal rays III,8, and a brown color with numerous white spots and black saddle-like areas along the back. It is recorded from several islands of the Indian Ocean, the western Pacific, and in Oceania from Tahiti, Nauru, and the Caroline Islands. We collected the species at Washington Island in the Line Islands and the Ryukyus.

Grammistes sexlineatus also has a flap on the chin but it is very small. It is otherwise distinguished by dorsal rays VII,13 or 14; anal rays II,9 and its dark brown to black color with bright yellow stripes. Juveniles have 3 such stripes on the side; these increase in number to 8 in adults, and they break up into series of dashes on large adults. This fish has the broadest distribution of all the soapfishes: east Africa to French Polynesia, and it is the most common of the Indo-Pacific species.

Grammistes lineatus ARnourt (1958) is a synonym of Grammistes sexlineatus.

FOwLER's separation of a subspecies, Grammistes sexlineatus proerythraeus, based on a single $33 \mathrm{~mm}$ specimen from the Ryukyus, is not tenable. 


\section{Acknowledgments}

This study was supported by a grant from the Japan Society for the Promotion of Science as a part of the Japan-U. S. Cooperative Science Program and by U. S. Public Health Service Grant UI-00216 for the study of marine toxins of the Pacific. We wish to thank A. H. BAnner of the University of Hawaii, the Principal Investigator of the latter program for his critical review of the manuscript. Thanks are also due Tokiharu AвE of the Tokai Regional Research Laboratory, Chuichi ARAga of the Seto Marine Biological Laboratory, Kyoto University, Marie Louise BaUchot of the Muséum National d'Histoire Naturelle (MNHN) in Paris, Earl S. Herald of the Steinhart Aquarium in San Francisco, Harry T. Kami of the Division of Fish and Wildlife of the Government of Guam, Robert H. Kanazawa and Victor G. Springer of the United States National Museum (USNM), A. C. WheELer of the British Museum (Natural History), and Fujio YASudA of the Laboratory of Fishery Biology of the University of Tokyo for specimens of fishes or information on specimens. The senior author also wishes to acknowledge the use of the facilities of the Seto Marine Biological Laboratory, the Eniwetok Marine Biological Laboratory, the Department of Marine Sciences of the University of Puerto Rico, and the vessel "Cuckoo's Nest" of Mr. Edwin Janss.

\section{REFERENCES}

Arnoult, J., M.-L. Bauchot-Boutin and R. Roux-Estève, 1958: Les poissons de L'ile Aldabra. Ann. Inst. Océanogr. Paris N. S., 34, pp. 47-90.

Blezкer, P., 1857: Achtste bijdrage tot de kennis der vischfauna van Amboina. Act. Soc. Sci. IndoNeerl., 2, pp. 1-102.

-_ 1874: Poissons de Madagascar et de l'ile de la Reunion. In "Recherches sur la fauna de Madagascar...", Pt. 4, pp. 1-106.

Bliss, R., 1883: Descriptions of new species of Mauritian fish. Trans. Soc. Roy. Arts Sci. Maurice, $13, \mathrm{pp} .45-63$.

Blogh, M. E. and J. G. Schnemer, 1801: Systema Ichthyologiae. T-Lx + 1-584 pp. J. Cramer, Berlin.

Boulenger, G. A., 1895: Catalogue of the fishes in the British Museum. Vol. 1. I-Xix + 1-394 pp. Taylor and Francis, London.

Boylan, D. B. and P. J. Scheuer, 1967: Pahutoxin: a fish poison. Science, 155 (3758), pp. 52-56.

Courtenay, JR., W. R., 1967: Atlantic fishes of the genus Rypticus (Grammistidae). Proc. Acad. Nat. Sci. Phila., 119 (6), pp. 241-293.

Fowler, H. W., 1946: A collection of fishes obtained in the Riu Kiu islands by Captain Ernest R. Tinkham A.U.S. Proc. Acad. Nat. Sci. Phila., 98, pp. 123-218.

Gilchrist, J. D. F. and W. W. Thompson, 1917: A catalogue of the sea fishes recorded from Natal. Pt. II. Ann. Durban Mus. 1, pp. 291-431.

Gosline, W. A., 1960: A new Hawaiian percoid fish, Suttonia lineata, with a discussion of its relationships and a definition of the family Grammistidae. Pacific Sci., 14 (1), pp. 28-38.

Gosline, W. A. and V. E. Brock, 1960: Handbook of Hawaiian fishes. 372 pp. Univ, of Hawaii Press, Honolulu, 
Greenwood, P. H., D. E. Rosen, S. H. Weitzman, and G. S. Myers, 1966: Phyletic studies of teleostean fishes, with a provisional classification of living forms. Bull. Amer. Mus. Nat. Hist., 131, Art. 4, pp. 341-455.

Günther, A., 1859: Catalogue of the Acanthopterygian fishes in the collection of the British Museum. Vol. 1. xxxi + 524 pp. Taylor and Francis, London.

- 1873: Andrew Garrett's Fische der Südsee I. Jour. Mus. Geodeffroy, 3, pp. I-IV + 1-128.

Hashimoto, Y. and H. Kamrya, 1969: Occurrence of a toxic substance in the skin of a sea bass Pogonoperca punctata. Toxicon, 7, pp. 65-70.

Hobson, E. S., 1965: Diurnal-nocturnal activity of some inshore fishes in the Gulf of California. Copeia, (3), pp. 291-302.

- 1968: Predatory behavior of some shore fishes in the Gulf of California. Res. Rept., Bur. Sport Fish. \& Wildlife, 73, pp. I-vi + 1-92.

Hubss, C. L. and Y. T. CHu, 1934: Asiatic fishes (Diploprion and Laeops) having greatly elongated dorsal ray in very large postlarvae. Occ. Pap. Mus. Zool. Univ. Mich., 299, pp. 1-7.

Jordan, D. S. and B. W. Evermann, 1905: The aquatic resources of the Hawaiian Islands, part I. The shore fishes. Bull. U. S. Fish Comm., 23 (1) (1903), I-XxvirI + 1-574 pp.

Kamohara, T., 1961: Colored Illustrations of the Fishes of Japan II. 1-168 pp. Hoikusha, Osaka. 1962: Notes on six additions to the marine fish fauna of Kochi Prefecture, Japan. Repts. Usa Mar. Biol. Sta., 9 (2), pp. 1-6.

___- 1964: Revised catalogue of fishes of Kochi Prefecture, Japan. Repts. Usa Mar. Bjol. Sta., 11 (1), pp. 1-99.

Katayama, M., 1959: Studies on the serranid fishes of Japan (I). Bull. Fac. Educ., Yamaguchi Univ., 8, pt. 2, pp. 103-180.

- $1960 \mathrm{a}$ : Studies on the serranid fishes of Japan (II). Bull. Fac. Educ., Yamaguchi Univ., 9, Pt. 2, pp. 63-98.

—_ 1960b: Fauna Japonica, Serranidae (Pisces). I-viII + 1-189 pp. Tokyo News Service, Ltd., Tokyo.

Kittlitz, F. H. von, 1858: Denkwürdigkeiten einer Reise nach dem russischen Amerika, nach Mikronesien und durch Kamschatka. Vol. 2, pp. 65-66, 101-102, and 123-126 (descriptions of fishes).

LAČ́pède, B. G. E., 1802: Histoire naturelle des poissons... Vol. 4. I-XLIV + 1-728 pp. Chez Plassan, Paris.

Liguori, V. R., G. D. Ruggieri, S. J., M. H. Baslow, M. F. Stempien, JR. and R. F. Nigrelli, 1963: Antibiotic and toxic activity of the mucous of the Pacific golden striped bass Grammistes sexlineatus. Amer. Zoologist, 3 (4), p. 302.

Maretzki, A. and J. Del Castillo, 1967: A toxin secreted by the soapfish Rypticus saponaceus. Toxicon, 4, pp. 245-250.

Norman, J. R., 1957: A draft synopsis of the orders, families and genera of recent fishes and fish-like vertebrates. 649 pp. Photolithographed, British Museum (Nat. Hist.), London.

Randall, J. E., 1967: Food habits of reef fishes of the West Indies. Stud. Trop. Oceanogr. (Univ. of Miami), (5), pp. 665-847.

Reeves, C. D., 1927: A catalogue of the fishes of northeastern China and Korea. Jour. Pan-Pacific Res. Inst., 2 (3), pp. 3-16.

Rofen, R. R. et al., 1963: Handbook of the food fishes of the Gulf of Thailand. Spec. Rept. no. 1, Aquatic Res. Inst., I-II + 1-236 pp.

Schultz, L. P., 1966: Pseudorhegma diagramma, a new genus and species of grammistid fish, with a key to genera of the family and to the species of the subfamily Pseudogramminae. Ichthyologica, 37 (4), pp. 185-194.

Schultz, L. P. and E. D. Reid, 1939: A revision of the soapfishes of the genus Rypticus. Proc. U. S. Natl. Mus., 87 (3074), pp. 261-270.

Smith, J. L. B., 1949: The sea fishes of Southern Africa. I-Xvi $+1-564$ pp. Central News Agency, Ltd., South Africa. 
1954: Aberrant serraniform fishes from East Africa. Ann. and Mag. Nat. Hist., Ser. 12, 7, pp. 861-872.

Sмith, J. L. B. and M. M. Sмiтн, 1963: The fishes of Seychelles. 1-215 pp. Dept. Ichthyology, Rhodes Univ., Grahamstown.

Thomson, D. A., 1964: Ostracitoxin: an ichthyotoxic stress secretion of the boxfish, Ostracion lentiginosus. Science, 146 , pp. 244-245.

_ 1968: Trunkfish toxins. Drugs from the Sea Symposium, University of Rhode Island 27-29 August 1967, pp. 203-211.

Tomryama, I., T. Abe and T. Tokioka, 1966: Encyclopedia Zoologica Illustrated in Colours. Vol. II. I-Xv + 1-392 pp. Hokuryu-kan Publishing Co., Ltd., Tokyo.

Waite, E. R., 1911: Additions to the fish fauna of the Kermadec Islands. Trans. and Proc. New Zealand Inst., 44, pp. 28-29.

Weber, M. and L. F. De Beaufort, 1931. The fishes of the Indo-Australian Archipelago. Vol. VI. I-XII + 1-448. E. J. Brill, Ltd., Leiden.

Whitley, G. P., 1968: A check-list of the fishes recorded from the New Zealand region. The Austral. Zool., 15, pt. 1, pp. 1-102.

Whitley, G. P. and A. N. Colefax, 1938: Fishes from Nauru, Gilbert Islands, Oceania. Proc. Linn. Soc. New South Wales, 63, pts. 3-4, pp. 282-304.

Woodland, D. J. and R. J. Slack-Smith, 1963: Fishes of Heron Island, Capricorn group, Great Barrier Reef. Univ. Queensland Pap., 2 (2), pp. 15-69.

Yasumoto, T., T. Watanabe and Y. Нashimoto, 1964: Physiological activities of starfish saponin. Bull. Jap. Soc. Sci. Fish., 30, pp. 357-364. 